\title{
Balancing Accountability and Effectiveness: A Case for Moderated Parliamentarism
}

\section{Tarunabh Khaitan*}

In this article, I bring two key issues in constitutional studies - institutional regime type and electoral system choice - in conversation with each other, and examine their interaction through a normative framework concerning the role that constitutions ought to play in shaping their party systems. The main goal is to offer a theoretical defense (ceteris paribus) of moderated parliamentarism - as superior to its alternatives such as presidentialism, semi-presidentialism, and other forms of parliamentarism.

Moderated parliamentarism entails a strong bicameral legislature in which the two chambers are symmetric (i.e. they have equal legislative powers) and incongruent (i.e. they are likely to have different partisan compositions). It has a centrist chamber whose main function is to supply confidence to the government, and a diversified chamber whose main function is to check this government. The confidence and opposition chamber is elected on a moderated majoritarian electoral system (such as approval vote or ranked-choice/preferential vote system, but not first-past-the-post); the diversified chamber - a fully independent checking and appointing chamber is constituted on a proportional representation model (moderated by a reasonably high threshold requirement for translating votes into seats). The confidence and opposition chamber is elected wholesale for shorter terms. It alone has the power to appoint and fire a unified political executive headed by a prime minister. The checking and

Tarunabh Khaitan is the Vice Dean and Professor of Public Law and Legal Theory at Faculty of Law, Oxford, and a Professor of Law and Future Fellow at Melbourne Law School. I am extremely grateful to Stephen Gardbaum, Colm O'Cinneide, Ros Dixon, Joel Colon-Rios, Aziz Huq, Kate O’Regan, George Tsebelis, Mark Tushnet, Tracy Lightcap, Vicki Jackson, Paul Yowell, Maria Cahill, Ngoc Son Bui, Elizabeth Hicks, Tom Daly, Cora Chan, Eoin Carolan and other colleagues for extremely helpful comments. Barnard Andary assisted with research, and Ken Kiat with references, for which I am very thankful. Mistakes remain mine. 
82 Khaitan, A Case for Moderated Parliamentarism

appointing chamber is independent of the confidence and opposition chamber as well as of the political executive; its members have longer and staggered terms.

Moderated parliamentarism combines the benefits of different regime types and electoral systems in a way that optimizes four key constitutional principles in relation to political parties: it protects the purposive autonomy of parties and enables their ability to keep the four democratic costs low; it serves the party system optimality principle by making it more likely that every salient voter type will have a party to represent it, but also distinguishes between governance parties (which are likely to dominate the confidence and opposition chamber) and influence parties (which will have a space in the checking and appointing chamber); it aids the party-state separation principle by giving significant (and over-weighted) checking powers to smaller parties in the checking chamber; and it promotes the anti-faction principle by distinguishing between smaller influence parties that are polarizing factions from those that are not factional (and punishing the latter a lot less severely than the former).

The traditional debates between presidentialism and parliamentarism, and between majoritarian and proportional electoral systems have endured for as long as they have because each system brings something attractive to the table. Moderated parliamentarism seeks to combine the most attractive elements of each - checks and balance from presidentialism, continuous precarity of the political executive from parliamentarism, anti-factionalism of majoritarian electoral systems, and political pluralism of proportional representation systems. Because these virtues are in tension, no system can maximize each of them without incurring a cost for another. Moderated parliamentarism is one way to optimize the virtues of each system and yet yield a stable and effective regime type. 
I. INTRODUCTION

II. Parties: An (IDEAlised) Functional AcCount

A. Parties as Intermediaries

1. Bidirectionality of Parties

2. Plenary Character of Parties

B. Key Costs Reduced by Parties

III. Constitutional Principles in Relation to Political Parties
A. The Purposive Autonomy Principle
B. The Party System Optimality Principle
C. The Party-State Separation Principle
D. The Anti-Faction Principle

IV. The Contours of Moderated Parliamentarism

A. Mapping Regime Type and Electoral Systems

B. Moderated Parliamentarism

1. Semi-Parliamentarism

2. Weighted Mulipartisanship

3. Mixed Bicameralism

4. Moderated Electoral Systems

5. Asynchronous Electoral Schedules

6. Deadlock-Resolving Conference Committees

V. In DeFEnCE of Moderated Parliamentarism
A. Purposive Autonomy Principle
B. The Party System Optimality Principle
C. The Party-State Separation Principle
D. The Anti-Faction Principle

VI. CONCLUSION

\section{Introduction}

Constitutional law scholars have long debated institutional separation of powers in search of a government that is simultaneously effective and accountable. Of the two basic regime types, parliamentary systems are thought to prioritise governmental effectiveness and regime stability, whereas presidential systems are seen as more accountable, albeit at the cost of governmental paralysis 
or regime instability. ${ }^{1}$ On the other hand, political scientists have long argued over whether an electoral system should seek to maximise governmental stability or its democratic representativeness. Majoritarian electoral systems seem to produce stable governments and a party system with two or three broad-church political parties. Proportional electoral systems tend to value democratic representation more, and create multipartisan systems with several smaller parties, often serving narrow or factional interests. Bipartisan systems with catch-all parties tend to exert a centripetal force on the system, moving politics towards the centre. Multipartisan systems with multiple small parties tend to exert centrifugal pressures on a politics, although legislative outcomes in a diversified, multipartisan, legislature can still be consensual. Even though it is clear that electoral systems and party systems significantly scramble the key expectations of any institutional separation of powers, constitutional law scholars have been slow to engage with the relevant political science scholarship - instead, they have often chosen to turn to other institutional solutions outside politics, such as accountability to courts, to 'fix' the deficiencies of their preferred model. It remains rare in political science literature, ${ }^{2}$ and rarer still in

1 See generally Tom Ginsburg \& Aziz Huq, How to Save a Constitutional Democracy (Chicago: University of Chicago Press, 2018) at 176-86.

2 For examples of influential political science studies that consider only two of these factors, see David J Samuels \& Matthew Shugart, Presidents, Parties, and Prime Ministers: How the Separation of Powers Affect Party Organization and Behavior (Cambridge: Cambridge University Press, 2010); Juan J Linz, "The Perils of Presidentialism” (1990) 1:1 Journal of Democracy 51; Juan J Linz, "Presidential or Parliamentary Democracy: Does It Make a Difference?" in Juan J Linz \& Arturo Valenzuela, eds, The Failure of Presidential Democracy: Comparative Perspectives (Baltimore: Johns Hopkins University Press, 1994) 3; Jose Antonio Cheibub, Presidentialism, Parliamentarism, and Democracy (Cambridge: Cambridge University Press, 2006) at 20. Exceptions that consider all three factors include George Tsebelis, Veto Players: How Political Institutions Work (Princeton: Princeton University Press, 2002) [Tsebelis, Veto Players]; Adrian Vatter, "Lijphart Expanded: Three Dimensions of Democracy in Advanced OECD Countries?" (2009) 1:1 European Political Science Review 125; Michael G Breen, "Federal and Political Party Reforms in Asia: Is There a 
constitutional studies literature, ${ }^{3}$ to study the three interlocking variables party systems, ${ }^{4}$ executive-legislative relations, and electoral systems simultaneously.

In this article, I will bring two key issues in constitutional studies institutional regime type and electoral system choice — in conversation with each other, and examine their interaction through a normative framework concerning the role that constitutions ought to play in shaping their party systems. It assumes that a democratic government needs to be stable/effective and representative/accountable at the same time. Recognising the inherent tension in the simultaneous pursuit of these goals, I offer yet another attempt to find that Goldilockean sweet-spot that satisfactorily optimises these competing objectives. This article provides a theoretical defence of moderated parliamentarism - as superior to its alternatives such as presidentialism, semipresidentialism, and other forms of parliamentarism. As an acontextual, ahistorical, analytic, inquiry I do not — and cannot — make an all-thingsconsidered case for the adoption of moderated parliamentarism everywhere. That kind of judgment will require a deep contextual appreciation of the histories, path dependencies, vested interests, extant power relations,

New Model of Federal Democracy Emerging in Ethnically Diverse Countries in Asia?” (2020) Government and Opposition 1.

3 For examples of constitutional studies that consider only two of these factors, see Bruce Ackerman, “The New Separation of Powers” (2000) 113:3 Harvard Law Review 633; Daryl J Levinson \& Richard H Pildes, "Separation of Parties Not Powers" (2006) 119:8 Harvard Law Review 2311 at 2312. Exceptions that consider the interaction of all three factors include Stephen Gardbaum, "Political Parties, Voting Systems, and the Separation of Powers" (2017) 65:2 American Journal of Comparative Law 229.

$4 \quad$ For Sartori, "a party system is precisely the system of interactions resulting from inter-party competition. That is, the system in question bears on the relatedness of parties to each other, on how each party is a function (in the mathematical sense) of the other parties and reacts, competitively or otherwise, to the other parties". Giovanni Sartori, Parties and Party Systems: A Framework for Analysis, vol 1 (Cambridge: Cambridge University Press, 1976) at 39 [emphasis in the original]. 
institutional legacies and much more in a given polity. ${ }^{5}$ Not only is this not a fine-grained contextual study, it isn't a big-N empirical analysis of different regime types either. The main purpose of this article is theoretical rather than practical: more than an appeal for its actual adoption by constitution makers, moderated parliamentarism should be seen as a yardstick to judge extant systems to assess their strengths and shortcomings holistically.

Moderated parliamentarism entails a strong bicameral legislature in which the two chambers are symmetric (i.e. they have equal legislative powers) and incongruent (i.e. they are likely to have different partisan compositions). In the pantheon of liberal democratic institutions, bicameralism is seen as a lesser, dispensable, god. A second legislative chamber can often be seen as a pointless luxury, or worse, a sinecure for retired politicians. Recent conceptualisation of the 'semi-parliamentary' form of government will, one hopes, move it higher up on at least the scholarly agenda. Ganghof conceptualises semi-parliamentary systems as the mirror image of the more familiar semi-presidential systems: semipresidential systems split the political executive into two offices (a President who appoints, and shares power with, a Prime Minister), but only one of them the Prime Minister — may be fired by the legislature; ${ }^{6}$ semi-parliamentary systems split the legislature into two chambers, only one of which has the power

5 Colomer, for example, argues that the choice of electoral system in particular depends on the existing party system: dominant or two party systems tend to choose majoritarian systems, while multipartisan systems favour proportional systems: Josep Colomer, "The Strategy and History of Electoral System Choice" in Josep M Colomer, ed, The Handbook of Electoral System Choice (London: Palgrave Macmillan, 2004) 3.

6 That said, Sedelius and Linde have highlighted a key sub-division between semi-presidential systems in which the President as well as the legislature may fire the Premier and those in which the legislature alone may do so: Thomas Sedelius \& Jonas Linde, "Unravelling Semi-Presidentialism: Democracy and Government Performance in Four Distinct Regime Types” (2018) 25:1

Democratization 136 at 138 . Their key argument is that the latter sub-type (where the legislature alone can fire a Prime Minister appointed by the President) behaves similar to a parliamentary regime, and — in general performs much better than the former sub-type (where the President not only appoints, but can also fire the Prime Minister). 
to fire the (unified) political executive. ${ }^{7}$ I propose moderated parliamentarism as a sub-type of semi-parliamentarism, with a centrist chamber whose main function is to supply confidence to the government, and a diversified chamber whose main function is to check this government. The centrist confidence and opposition chamber is elected on a moderated majoritarian electoral system (such as approval vote or ranked-choice/preferential vote system, but not first-pastthe-post); the other diversified chamber - a fully independent checking and appointing chamber - is constituted on a proportional representation model (moderated by a reasonably high threshold requirement for translating votes into seats). The confidence and opposition chamber is elected wholesale for shorter terms. It alone has the power to appoint and fire a unified political executive headed by a prime minister. The checking and appointing chamber is independent of the confidence and opposition chamber as well as the political executive; its members have longer and staggered terms. Moderated parliamentarism therefore shares with semi-parliamentarism the feature that both chambers have direct democratic legitimacy; however, it avoids a legitimacy tie between them by ensuring that the confidence and opposition chamber as a chamber - always has a temporally more recent mandate.

I make a case for moderated parliamentarism by examining democratic regime-types through the lens of the democratic function of political parties. This lens is particularly apt because the recent wave of democratic deconsolidation in several established democracies has been accompanied by the collapse, authoritarian takeover, or external capture of mainstream political parties, the partisan capture of state institutions, and a rise in hyper-nationalistic and exclusionary partisan rhetoric. ${ }^{8}$ While political parties have long been a

7 Steffen Ganghof, “A New Political System Model: Semi-Parliamentary Government” (2018) 57:2 European Journal of Political Research 261 at 261.

8 Richard S Katz \& Peter Mair, Democracy and Cartelization of Political Parties (Oxford: Oxford University Press, 2018) at ch 7; Tarunabh Khaitan, "Executive Aggrandizement in Established Democracies: A Crisis of Liberal Democratic Constitutionalism” (2018) 17:1 International Journal of Constitutional Law 736; Peter Mair, Ruling the Void: The Hollowing of Western Democracy (New York: Verso, 2009); Tarunabh Khaitan, "Killing a 
central object of study in political science, constitutional theory scholars have, by and large, ignored this key democratic institution. ${ }^{9}$ In part, this has been due to the influence of the American and the British constitutional traditions which, unlike their European continental counterparts, are largely silent on political parties. This silence is largely a feature of big-C constitutional codes in the anglophone world. ${ }^{10}$ Small-c constitutional statutes, conventions, and judicial precedents in these states do, admittedly, engage extensively with political parties. ${ }^{11}$

But the large- $C$ textual silence is nonetheless indicative of the level of salience this key constitutional institution has been given, both in constitutional practice and constitutional scholarship. More substantively, big-C codes largely design key state institutions in a democracy. Parcelling off considerations about political parties to small-c statutes and conventions has the effect that the party system has to take the design of key state institutions as a given. As this article argues, however, bringing parties to the forefront of the constitutional imagination has very important implications for how we ought to think of fundamental institutions and offices of the state. Furthermore, big-C constitutional change tends to require the buy-in of opposition parties, whereas small-c changes can usually be made by the ruling party/coalition alone. It is simply bad design to

Constitution with a Thousand Cuts: Executive Aggrandizement Party-State Fusion in India” (2020) 14:1 The Law \& Ethics of Human Rights 49; Mark A Graber, Sanford Levinson \& Mark V Tushnet, eds, Constitutional Democracy in Crisis? (Oxford: Oxford University Press, 2018) 1.

9 Honourable exceptions, most of them cited in this article, do exist (although many of these works focus on particular jurisdictions rather than general constitutional theory).

10 On the post-war constitutionalization of political parties in continental Europe, see Ingrid Van Biezen, "Constitutionalizing Party Democracy: The Constitutive Codification of Political Parties in Post-war Europe" (2012) 42:1 British Journal of Political Science 187. See also Sujit Choudry, "Resisting Democratic Backsliding: An Essay on Weimar, Self-Enforcing Constitutions, and the Frankfurt School" (2018) 7:1 Global Constitutionalism 54.

11 On the big-C and small-c aspects of a constitution, see Anthony King, The British Constitution (Oxford: Oxford University Press, 2007) at 3. 
let one of the competing players unilaterally change the rules of the game. It is no surprise that continental big-C codes, led by Germany after the Second World War, are far more explicit in their attention to parties and their relationship with democracy. To be clear, I am not arguing that all arrangements concerning political parties and electoral systems must be included in the big- $\mathrm{C}$ constitution. What I am suggesting, however, is that normative considerations that go into institutional design of key state institutions should be factored at the same time as (rather than prior to) assessments concerning the type of party systems and electoral systems a state should have. There may well be good reasons to include the design of the electoral system in a small-c constitutional statute rather than in the big-C constitution, as long as the system ensures that the small-c constitutional statute cannot be amended for partisan gain by the ruling party acting alone. The key points, therefore, are these: (i) constitution makers must recognise that institutional arrangements, party systems, and electoral systems impact each other in complex ways, and no single one of them can be crafted in isolation, and (ii) these three features together determine the foundations of a political democracy and, therefore, warrant broad political consensus between key parties when they are being framed or changed.

The big-C Anglophone constitutional silence is mimicked in comparative constitutional studies scholarship, dominated as it is by American constitutional discourses. It is almost impossible to properly understand the functioning of different institutional arrangements without a close attention to the party system in which they operate. ${ }^{12}$ To be sure, a case for an institutional arrangement that looks similar to moderated parliamentarism can be made, and has been made, ${ }^{13}$ without considering party systems or electoral systems. Ackerman's constrained parliamentarism model might have been less hostile to symmetric bicameralism

12 See generally, Cindy Skach, "Political Parties and the Constitution" in Michel Rosenfeld \& Andras Sajo, eds, The Oxford Handbook of Comparative Constitutional Law (Oxford: Oxford University Press, 2012) 874 at 874.

13 Bruce Ackerman's advocacy of constrained parliamentarism in an influential and excellent paper is sensitive to party systems and electoral systems. Yet, it relies on traditional institutional premises deriving from separation of powers alone, and is deficient to that extent: Ackerman, supra note 3. 
in federal states, ${ }^{14}$ and incongruent bicameralism in unitary ones, ${ }^{15}$ had it paid more attention to party systems and electoral systems alongside institutional separation of powers. These additional considerations reveal the attractions of symmetric and incongruent (i.e. strong) bicameralism, as long as they are suitably moderated, without the pitfalls that Ackerman identifies. Constitutional scholarship that confines itself to normative institutional analysis alone, without simultaneously considering party systems and electoral systems normatively, is looking at a seriously distorted picture of constitutional practice.

This article brings three distinct dimensions of constitutional studies in conversation with each other: (i) a debate on the appropriate regime type for a democracy (discussed from a normative perspective informed by the 'separation of powers' principle by constitutional lawyers, ${ }^{16}$ and a more instrumental, impact-based, analysis by political scientists), ${ }^{17}$ (ii) a debate on appropriate electoral systems (mostly engaged in by political scientists), ${ }^{18}$ and (iii) the nondebate on the constitutional regulation of political parties (except doctrinally, in particular jurisdictional settings). The article starts with the non-debate in item (iii) of this list. Borrowing extensively from a recent paper on political parties in

$14 \quad$ Ibid at 672.

15 Ibid at 684. On the possibility that bicameral incongruence actually decreases the time taken to form a coalition government, see Daniela Giannetti, Andrea Pedrazzani \& Luca Pinto, "Bicameralism and Government Formation: Does Bicameral Incongruence Affect Bargaining Delays?” (2020) 12:4 European Political Science Review 469.

16 Jeremy Waldron, Political Political Theory (Cambridge: Harvard University Press, 2016); Ackerman, supra note 3; Nick W Barber, The Principles of Constitutionalism (Oxford: Oxford University Press, 2018); Aileen Kavanagh, "The Constitutional Separation of Powers" in David Dyzenhaus \& Malcolm Thornburn, eds, Philosophical Foundations of Constitutional Law (Oxford: Oxford University Press, 2016) 221.

17 Linz, supra note 2; Cheibub, supra note 2; Tsebelis, Veto Players, supra note 2.

18 Erik S Herron, Robert J Pekkanen \& Matthew S Shugart, eds, The Oxford Handbook of Electoral Systems (Oxford: Oxford University Press, 2018); Bartlomiej Michalak, "Mixed Electoral Systems: A Hybrid or a New Family of Electoral Systems?” (2016) 12:1 World Political Science 87. 
constitutional theory, ${ }^{19}$ Part II will first provide an idealized functional account of political parties and party systems. The idealised (and, therefore, normative) account presented in Part II clarifies what parties do when they function as they should function in a healthy party system of a representative democracy. Here, I will acknowledge that parties are difficult to regulate constitutionally because of their Janus-faced public-private character. The key function they perform, when functioning as they ought to function, is to facilitate a mutually responsive relationship between public policy and popular opinion by acting as an intermediary between a state and its people. When they perform this function effectively, political parties significantly reduce four key information and transaction costs which would otherwise make democratic governance impossible: political participation costs, voters' information costs, policy packaging costs, and ally prediction costs. In Part III, which also borrows from the aforementioned previous paper, I will use this idealised account to ground four principles that constitutions should seek to optimise in relation to political parties with a view to avoiding, curing, or mitigating these pathologies. These four distinct, and sometimes conflicting, constitutional principles in relation to political parties are that:

1. Constitutions should guarantee maximum autonomy for the formation, organisation, and operation of political parties, moderated by the restrictions necessitated by their purpose of winning (a share in) state power (for fixed terms) in competitive elections by acting as intermediaries between the state and its people (the 'purposive autonomy principle');

2. Constitutions should try to optimise the party system such that the total number of serious political parties is large enough to broadly represent every major 'voter type', but not so large that the information costs on judicious voters are too high (the 'party system optimality principle');

19 Tarunabh Khaitan, "Political Parties in Constitutional Theory" (2020) 73 Current Legal Problems 89 [Khaitan, "Political Parties"]. 
3. Constitutions should ensure a separation of parties and the state (the 'party-state separation principle'); and

4. Constitutions should discourage the factionalization of political parties (the 'anti-faction principle').

These political principles are drawn from the value of democracy itself. If effectively realized, they could bring real world political parties and party systems closer to their idealised form as described in Part II, thereby improving and deepening democratic governance. As such, they should — alongside other relevant political and constitutional norms — inform fundamental constitutional design choices. Retrofitting the regulation of parties through the small-c constitution after key design choices have already been made in the big$\mathrm{C}$ code is, therefore, a mistake. Big-C constitutional silence on parties is as much a regulatory choice as any other, and carries significant risks of unintended consequences. In other words, big-C constitutions - as the chief organizational tool for public power in democracies - simply do not have the option of remaining agnostic about the nature and functioning of political parties. The question is not so much whether to regulate parties, but why and how.

Part IV first explains why it is preferable, where feasible, for constitutions to respect and optimize these principles through second-order regulation which seeks to organise the political architecture in a manner that incentivise voluntary conformity with these principles, rather than by command-and-control first order regulation (usually enforced through courts). It then outlines the broad contours of moderated parliamentarism. It does so by locating moderated parliamentarism in an overlapping matrix comprising regime type and electoral systems. A system's regime type depends on three key factors:

1. whether the political executive and/or the legislature are unified/unicameral or divided/multicameral;

2. what is relationship between the president and the premier in a divided executive, and between the several chambers in a multicameral legislature; and 
3. what is the relationship between the political executive (or a part thereof, if divided) and the legislature (or a part thereof, if multicameral).

Its electoral system, on the other hand, depends on several factors, of which four fundamental ones are:

1. the district magnitude (single-member, multi-member, or at large);

2. the object(s) of voter choice (candidate, party, or both);

3. the ballot structure (categorical or dividual, cardinal or preferential); and

4. the electoral schedule (simultaneous or asynchronous, staggered or wholesale).

These features can be combined in innumerable permutations and combinations. Political scientists have recognised, ${ }^{20}$ but lawyers still haven't, that it is more or less pointless to discuss regime type without simultaneously examining the system's electoral system. Part IV teases out the details of the way in which moderated parliamentarism combines various features of executivelegislative relations and electoral systems.

Part $\mathrm{V}$ then argues that moderated parliamentarism combines the benefits of different regime types and electoral systems in a way that optimizes the proposed constitutional principles, and — context permitting — can be a good theoretical model for representative democracies. Moderated parliamentarism protects the autonomy of parties and enables their ability to keep the four democratic costs low. It serves the party system optimality principle by making it more likely that every salient voter type will have a party to represent it, but also distinguishes between governance parties (which are likely to dominate the confidence and opposition chamber) and influence parties (which will have a space in the checking and appointing chamber). Moderated parliamentarism aids the party-state separation principle by giving significant checking powers to smaller parties in the checking chamber. It also protects the unelected state from

20 Robert Elgie, "From Linz to Tsebelis: Three Waves of Presidential/Parliamentary Studies?” (2005) 12:1 Democratization 106. 
capture by the ruling party by over-weighing the say of the larger small parties in the checking and appointing chamber in constitutional appointments ("weighted multipartisanship"). Finally, it checks factionalism by making it more difficult for factions (i.e. 'parties' whose policies are not justifiable to all the people, as explained later in this article) to win big in the confidence and opposition chamber. At the same time, the moderated majoritarian electoral system of this chamber incentivises factions to become broad church parties if they wish to become parties of governance.

Ultimately, the principle informing moderated parliamentarism is that the traditional debates between presidentialism and parliamentarism, and between majoritarian and proportional electoral systems have endured for as long as they have because each system brings something attractive to the table. Moderated parliamentarism seeks to combine the most attractive elements of each checks and balance from presidentialism, continuous precarity of the political executive from parliamentarism, anti-factionalism of majoritarian electoral systems, and political pluralism of proportional representation systems. Because these virtues are in tension, no system can maximise each of them without incurring a cost for another. Moderated parliamentarism is one way to optimize the virtues of each system and yet yield a stable regime type. Part VI concludes.

\section{Parties: An (Idealised) Functional Account ${ }^{21}$}

In a previous paper, I had argued that political parties, when they function as political parties ought to function, perform the key democratic function of acting as an intermediary between the state and its people in a representative democracy. Two particular features make this intermediary function of parties unique: the bidirectionality of their intermediation and the plenary character of political parties. A party system with healthy functional parties incurs lower levels of four key information and transaction costs: political participation costs, voters' information costs, policy packaging costs, and ally prediction costs. Keeping these costs low makes a representative democracy viable as a mode of

21 This part provides a summary of the arguments made in more detail in:

Khaitan, "Political Parties", supra note 19, section 2. 
governance. In this part, I will briefly summarise these previous claims to lay the foundations for the argument in this article.

\section{A. Parties as Intermediaries}

The chief function of political parties is to act as intermediaries between the state and its people. This claim does not presuppose a specific type of party organisation: I use the term 'intermediary' in a loose sense here to be compatible with a varying range of intensity in the relationship between the party and the people. ${ }^{22}$ What matters is that parties have a threshold level of communicative relationship with the people. State officers and institutions are typically too removed from the people to access popular opinions directly, and ordinary civil society organizations are usually too removed from the state to influence state policies. Exceptions no doubt exist: in systems where individual legislators represent sufficiently small constituencies, they can have a direct relationship with their constituents; similarly, many policy influencers, such as lobbyists, thinktanks, and powerful media houses, can often have significant influence on state policy. Yet, political parties are a very special type of intermediary between the state and its people for two reasons: the bidirectionality and the plenary character of their intermediary function.

22 Thus, cadre-based parties, mass-parties, and parties that act as 'brokers' between the state and the people are all capable of acting as intermediaries. On these categories, see generally Richard S Katz \& Peter Mair, "Changing Models of Party Organization and Party Democracy: The Emergence of the Cartel Party" (1995) 1:1 Party Politics 5. Katz and Mair's thesis concerning "cartel parties", on the other hand, concerns the relationship between political parties and the state: as we will see later while discussing the party-state separation principle, cartelization is an indication of a pathological party system. See also, JanWerner Müller, “Democracy's Critical Infrastructure: Rethinking Intermediary Powers" (2021) 47:3 Philosophy \& Social Criticism 269, who highlights the importance of the intermediary role that political parties play, alongside the media. Müller's paper was published after this article was finalised, so its insights could not be used to inform the main text of this article. 


\section{Bidirectionality of Parties}

Mediation by parties is bidirectional, in as much as they simultaneously perform both functions of accessing popular opinion and shaping state policy. They are embedded in the structures and institutions of the state, but also (at least ideally) have direct access to the people. This simultaneity is essential to the democratic legitimation that parties alone can provide to rule-making state institutions and offices. In general, the state functions through offices and institutions: these are modes of corporate action that are defined by a measure of formalization of their processes, purposes, and modes of operation. This formalization is typically necessary for satisfying various virtues associated with the state: impartiality, rationality, fairness, legality, and so on. But formalization imposes a cost - it reduces the ability of offices and institutions to connect with the people affectively, and build authentic interpersonal relationships of mutual understanding and dialogue. Parties, on the other hand, despite their internal institutionalized structures, retain the potential for flexibility and informality of civil society organizations - at least at their local units. This measure of informality allows them to perform their key coordinating function: to imbibe and influence popular opinion on the one hand and to formulate and justify their proposed policy package on the other. The relationship between popular opinions and policy packages is mutually responsive - in a well-functioning democracy, they respond to each other and form a feedback loop. The central task of political parties is to facilitate this responsive relationship between popular opinion and policy. ${ }^{23}$ Sometimes, they absorb popular opinions and translate them into policy proposals. At other times, they articulate policy proposals and mould public opinion to get behind them.

\section{Plenary Character of Parties}

The second special feature of the mediation role that well-functioning parties play between the state and its people is their plenary character. In heterogenous

23 See generally Nancy L Rosenblum, "Political Parties as Membership Groups" (2000) 100:3 Columbia Law Review 813 at 825-26; Barber, supra note 16 at $170-71$. 
societies, the values as well as the interests of the people are likely to be diverse. Value pluralism as well as interest pluralism pose a huge challenge to the ability of the state to frame public policy that would be broadly acceptable to its people. The ways in which different values and interests may combine are so staggeringly large that any complex society faces the potential problem of being left with most of its population being perennially disgruntled. Parties (when they function well) perform a significant legitimation function for the state by coalescing around distinct families of values — often described as ideology and aggregate the diverse interests of (all) the people of a state into a coherent policy package more-or-less compatible with their ideology. The policy package need not be internally coherent — it often involves the weighing of various interests, preferences, and values. It may entail a multitude of compromises that seek to bridge the gap between the ideal and the feasible, and must frequently cater to logically opposed interests, values, and preferences.

The internal contradictions of the policy package of a well-functioning political party notwithstanding, the party can claim that its mediation has a plenary character in three distinct senses: first, it mimics the plenary nature of governance, which is at least potentially concerned with all issues affecting human flourishing (as well as with interests of non-human animals). No state can decide to have a policy only on healthcare, for example. Even its silence or inaction on all other matters will amount to a policy decision, which it would be well-advised to adopt deliberately rather than inadvertently. As the drivers of governments-in-waiting, governance parties come up with policies on a wide range of issues, drawing upon their interaction with the people, and then seek to sell them politically to the people as a package. In doing so, they persuade their supporters to accede to certain compromises made with their own values, interests, and preferences so long as the overall policy package remains attractive to them. These policy platforms also make the opportunity costs of their policy packages transparent to voters, who are better able to prioritise their preferences in a context of resource constraint.

The policy package of a party is also plenary in a second sense: it is one that is designed by putting the interests of all the people on the scales. I will shed 
further light on this feature when discussing the anti-faction principle. For now, it will suffice to note that parties should consider the well-being of all the people: any political group that a priori dismisses the interests of any section of the population as either irrelevant to its policy considerations or worse, meriting its hostility, is no longer committed to the rule of all the people, and is basically a faction rather than a party.

Third, parties have a plenary character inasmuch as they are more likely than most other political actors in electoral democracies to have long-term horizons, and therefore are likely to care more about the interests of the future people. As Rosenbluth and Shapiro correctly state, "parties have reputations that outlive those of individual politicians, and to the extent that they must represent a wide view of societal interests, they are more capable of delivering desired outcomes than any amount of direct democracy, and more trustworthy than even the most appealing individual politician". ${ }^{24}$ This feature adds a temporal dimension to the inclusive plenary character of parties.

\section{B. Key Costs Reduced by Parties}

In providing this uniquely bidirectional and plenary mediation between the state and its people, political parties (in efficient multipartisan systems) ${ }^{25}$ reduce key information and transaction costs for both, making representative democracy possible. ${ }^{26}$ Parties are able to reduce the costs I am about to discuss mainly in well-functioning party systems. Multipartisan systems — defined by the number of parties they have and the nature of the interaction between them - may be more or less efficient at reducing these costs. Other things being

24 Frances McCall Rosenbluth \& Ian Shapiro, Responsible Parties: Saving Democracy from Itself (New Haven: Yale University Press, 2018) at 230.

25 A single party, in a one-party system, cannot reduce these costs. But then, many of these costs usually only matter in multiparty systems with competitive elections.

26 It should be obvious that I am assuming the normative desirability of "substantive" over merely "formal", "symbolic", or "descriptive" representation: see generally Hanna Fenichel Pitkin, The Concept of Representation (Los Angeles: University of California Press, 1967). 
equal, constitutions will deepen democracy if they make their party systems and parties more efficient at reducing the following costs.

First, healthy parties in efficient party systems reduce the transaction costs of political participation for citizens (political participation costs). Even in a smallish party-less direct democracy, an ordinary citizen acting on her own would almost certainly need to take up political engagement as a full-time occupation to have any hope of making a modicum of difference to state policy. A sortition-based democracy may well facilitate significant political participation for many people, but not necessarily with respect to specific political concerns a particular citizen wants to engage with. Sooner or later, a politician will have to invent something that looks like a political party to enable some political engagement by citizens who do not wish to become full-time politicians. Parties also reduce the transaction costs of political participation for citizens - not only for partisans, but also for non-partisan citizens - who, in a well-functioning pluralistic democracy, are likely to find some party that reflects their values and priorities most closely and could therefore be their first port of call when raising a matter of political concern. ${ }^{27}$ The mere existence of any person or group that is permanently excluded from the political process because their participation cost is too high changes the very character of the regime.

Secondly, parties reduce information costs. In constituencies whose large size is typical of contemporary states, voters tend to lack personal knowledge of electoral candidates. Given modern population levels, it is usually not feasible to have constituencies so small that most voters are personally sufficiently acquainted with all candidates. Parties reduce the information costs for voters because party affiliations of different candidates provide them with significant amount of broadly accurate proxy information about their political views and agendas, thereby reducing their voters' information costs.

Third, parties also reduce information costs for democratic state institutions by revealing to them what combination of policies will be acceptable to what

27 Matteo Bonotti, Partisanship and Political Liberalism in Diverse Societies (Oxford: Oxford University Press, 2017) at 33-34. 
proportion of the people. All parties that campaign on policy packages provide this information to state institutions, whether they win or lose. ${ }^{28}$ And winning parties, in addition, inform state institutions about the particular policy packaging that a large proportion of — if not a majority of — the people are willing to at least tolerate. This information can be generated and revealed, and state policy be legitimised, only through the bidirectional and plenary character of the mediating function that parties perform. Let us label these information and transaction costs the policy packaging costs.

Finally, parties reduce information costs for other political parties as well as for state officers and institutions by indicating to them which office-holders are likely to be persuadable political allies, whose support can be taken for granted, and who are likely to oppose certain policy proposals. Moreover, when they are reasonably disciplined, parties permit the identification of key leaders whose support will likely translate into the support of a predictable number of legislators and what it might take to secure their support. By aggregating and publicising political leanings, parties reduce the information costs associated with discovering whether another political actor is a political friend or foe, and the consequent transaction costs in making political decisions (ally prediction costs).

A democracy cannot function without these costs remaining low. ${ }^{29}$ Parties reduce these costs by acting as intermediaries between the state and its people, on the one hand transmitting popular opinion to state institutions that typically lack the ability to gauge it directly, and on the other hand formulating state policies and justifying them to the people. This dual role gives them a Janusfaced public-private character - they need to operate as a private association

28 Almond identifies the political party as the distinctive modern political structure for "interest aggregation", as distinct from "interest articulation" that can be done by special interest groups. See Gabriel Almond, "Introduction: A Functional Approach to Comparative Politics" in Gabriel Almond \& James Coleman, eds, The Politics of the Developing Areas (Princeton: Princeton University Press, 1960) 3 at 38-39.

29 See Khaitan, "Political Parties", supra note 19 at $98 \mathrm{f}$ to understand why. 
proximate to the people in order to access popular opinions and justify state policies. They also simultaneously need to be embedded in (but not fused with) the institutional structures of the state to transmit popular opinions back to them and to help them formulate policies, which in turn they will help justify to the people. Although my account is an idealised one, keeping these costs low does not make a representative democracy utopian in any sense. Lowering these democratic costs are best seen as key aspirations, alongside several others, that democracies should constantly strive to realize.

\section{Constitutional Principles in Relation to Political Parties ${ }^{30}$}

The previous part offered an idealised account of what parties do in a wellfunctioning democratic system. This idealised account is helpful in distinguishing parties and party systems that function well from those that are pathological. Parties that fail to perform their intermediary function appropriately and effectively are bad for democracy. A healthy party system can tolerate a few malfunctioning parties, so long as most of the key players are sound. In this part, I will summarise certain constitutional principles I have defended elsewhere — principles that constitutions ought to adopt in relation to parties in order to make it more likely that parties and party systems are healthy; or that — if there are diseased parties in the system — the system can still tolerate or mitigate their ill effects.

These are the four principles that constitutions should respect and optimize in relation to parties:

1. They should guarantee maximum autonomy for the formation, organisation, and operation of political parties, moderated by the restrictions necessitated by their purpose of winning (a share in) state power (for fixed terms) in competitive elections by acting as intermediaries between the state and its people (the 'purposive autonomy principle');

30 This part is a summary of Khaitan, ibid, section 3. 
2. They should try to optimise the party system such that the total number of serious political parties is large enough to broadly represent every major 'voter type', but not so large that the information costs on judicious voters are too high (the 'party system optimality principle');

3. They should ensure a separation of parties and the state (the 'partystate separation principle'); and,

4. They should discourage the factionalization of political parties (the 'anti-faction principle').

I hasten to add two caveats to this proposal: first, I do not take constitutionalization to necessarily entail judicialization. ${ }^{31}$ In fact, sometimes it may be neither necessary nor desirable to express a constitutional principle as a constitutional norm directly regulating constitutional actors, let alone as a legal norm. Instead, establishing an institutional arrangement that is most likely to uphold that principle — what may be termed 'second order' regulation — may well be the most optimal design solution.

Second, a norm can be 'constitutionalised' in multiple ways, its inclusion in a big-C constitutional code being only one of them. Other modes of constitutionalization include judicial interpretation, quasi-constitutional statutes, and constitutional conventions. The principles to be discussed should ideally inform — at least at a broad level — the big-C constitutional code so that the institutional arrangements of the state are framed alongside its party system, rather than ex ante. The finer details will, obviously, need to be left to the small-c statutes, conventions, and caselaw. The key determinant in a given context should, in the main, be feasibility and effectiveness. The following subsections will briefly explain each of these principles in turn.

31 Waldron, supra note 16; Tarunabh Khaitan, "Constitutional Directives: Morally-Committed Political Constitutionalism” (2019) 82:4 Modern Law Review 603 [Khaitan, "Constitutional Directives"]. 


\section{A. The Purposive Autonomy Principle}

Constitutional law continues, on the whole, to adhere to a sharp public-private divide, vesting private actors with constitutional rights and burdening public actors with constitutional duties. ${ }^{32}$ This structural limitation is an important hurdle that must be overcome if constitutions are to properly regulate political parties without destroying their public-private duality. While constitutions must be careful about over-regulating political parties lest they destroy their private character, they should also worry about constitutional silences and underregulation that fails to acknowledge their publicness. A fit-for-purpose constitutional scheme for political parties will pay attention to three dimensions: (i) subject to the principles discussed in this article, it will grant them maximum autonomy, (ii) it will vest in them the necessary rights, powers, and entitlements which will enable them to better discharge their functions, and (iii) it will impose only those duties on parties that are necessary to preserve their public character. Is there such a happy regulatory middle which would preserve their privateness while demanding that they be sufficiently public at the same time?

To locate that regulatory middle, we need to point out with greater precision what precisely makes parties public. The private dimension of parties demands maximum autonomy for the formation and operation of political parties. But their public character demands a recognition of their purposive dimension: unlike natural individuals, political parties in a representative democracy cannot be allowed to choose their purpose with complete freedom. What makes them a political party in a democratic party system is their public purpose of participating in competitive elections - with other parties - in order to secure (significant) control of the levers of state power for fixed periods of time, and to do so by acting as intermediaries between the state and the people. This purpose is definitional of what a political party in a democracy is. It is specified at a high level of generality, being compatible with an extremely wide range of more

32 British Human Rights Act 1998 (UK), s 6 is a notable exception. So is the horizontal application of certain fundamental rights in some jurisdictions, such as South Africa. 
specific purposes that parties may have. But it is incompatible with certain purposes: such as instituting a single party state, making elections insufficiently competitive, barring or making it difficult for (other) parties to connect or communicate with the people, and so on.

It follows then that constitutions should guarantee maximum autonomy for the formation (from scratch or by splitting an existing party), organisation, and operation of political parties, moderated by the restrictions necessitated by their purpose of winning (a share in) state power (for fixed terms) in competitive elections by acting as intermediaries between the state and its people. Hence the purposive autonomy principle. Simply put, the principle permits significant autonomy to parties (and partisans), but seeks to ensure that there are committed to the purpose of being but one player in a multiparty democracy. The principle requires that parties should be relatively easy to form and disband, and to enter or leave. The main barriers to their success should be political, not legal or financial. New parties or opposition parties must not be locked out of political competition through high entry barriers. ${ }^{33}$ In general, parties may need the whole suite of civil and political rights that citizens ordinarily have access to in a liberal democracy; sometimes they may even need special protections of their autonomy over and above what citizens are guaranteed. Without these freedoms, a political party may be woefully inept at reducing key democratic costs.

While their privateness demands a protection of their autonomy, their public purpose may entitle them to special privileges and powers, as well as fit for bearing special duties that are inapplicable to natural individuals. Public entitlements, such as (limited) state funding for political campaigns or immunity from defamation laws for speeches made in legislatures, can help

33 For a catalogue of such barriers enacted against third parties in the United States, see Samuel Issacharoff \& Richard H Pildes, "Politics as Markets: Partisan Lockups of the Democratic Process" (1998) 50:3 Stanford Law Review 643 at 683 . 
secure a level playing field between political parties and enable many of them to discharge their democratic functions effectively. ${ }^{34}$

Finally, the public purpose of parties invites not only special entitlements but also some public duties. For example, parties are likely to lower the political participation costs only if there is a fair measure of transparency surrounding their core value commitments, internal institutional structures, decision-making processes, financial affairs, and credible - even if internal - enforcement mechanisms of their institutional commitments. Likewise, parties are likely to lower the policy packaging costs (as well as the other three democratic costs) only if they offer a more-or-less comprehensive policy package in their election manifestos.

Thus, the purposive autonomy principle seeks to preserve the public-private duality of political parties that is essential to their role in facilitating democratic governance. If we consider Article 21(1) of the German Basic Law, for example, it is broadly a recognition of the purposive autonomy principle:

The political parties participate in the formation of the political will of the people. They may be freely established. Their internal organisation must conform to democratic principles. They must publicly account for their assets and of the sources and use of their funds as well as assets. ${ }^{35}$

'Broadly', because it is doubtful that inner-party democracy — mandated by the third clause above — can be justified by the purposive autonomy principle. It is by no means obvious that internally democratic parties are better at reducing the key democratic costs, not to mention the pragmatic difficulties in determining what suffices as an internally democratic party at an age of relatively loose and myriad ways of associating with a party. ${ }^{36}$ Constitutions should also

\footnotetext{
34 Article 40 of the Constitution of Portugal, for example, guarantees broadcasting time in public media to political parties.

35 See also Article 51 ibid.

36 See generally Kate O’Regan, "Political Parties: The Missing Link in Our Constitution?" (28 August 2015), online: Corruption Watch
} 
be slow to mandate inner-party democracy or regulate how parties discipline their members. Many courts have enforced fundamental rights claims by ordinary voters and party members against political parties. ${ }^{37}$ Doing so has clear, and often adverse, consequences for the purposive autonomy of political parties.

The purposive autonomy principle is a meta-principle that dictates how constitutions should approach political party regulation. The three following principles may be understood as facets of the purposive autonomy principle principles that highlight the publicness of parties that justify regulation. They merit separate discussion because of the important bearing they have for the constitutional regulation of parties.

\section{B. The Party System Optimality Principle}

Parties tend to have ideologies: a relatively wide-ranging belief system, which is relevant to political behaviour. ${ }^{38} \mathrm{~A}$ belief system, in turn, is "a configuration of ideas and attitudes in which the elements are bound together by some form of constraint or functional interdependence". ${ }^{39}$ The centrality of an element in a belief system is a measure of the likelihood that a voter will change her party preference if her party's stance regarding that element changes, rather than change her view on the element itself. ${ }^{40}$ She may tolerate a party's change of position on less central elements in a belief system, but give up on her partisan loyalty if the party reneges on a more central element. For Gerring, the quality of being 'bound together' (which he calls 'coherence') has two corollaries: contrast ('implying coherence vis-à-vis competing ideologies') and stability

$<$ www.corruptionwatch.org.za/political-parties-the-missing-link-in-ourconstitution/>.

37 Ramakatsa v Magashule, [2012] ZACC 31 (SA, Constitutional Court); Bhuttav Pakistan, [1998] PLD 370 (Supreme Court (PAK)).

38 Philip E Converse, "The Nature of Belief Systems in Mass Publics (1964)" (2006) 18:1-3 Critical Review 1 at 4-5.

39 Ibid at 3.

$40 \quad$ Ibid at 4. 
('implying coherence through time'). ${ }^{41}$ Thus, competing political ideologies straddle the same ideological axis and are relatively stable over time. While much penumbral content of political ideologies is malleable, their most central elements are likely to be most relevant to contrasting them it with other ideologies and to determine their stability over time. Not all ideologies matter politically: they ought to be politically salient. ${ }^{42}$

Sartori's classical account analysed party systems through a single-axis lens of left and right-wing parties. ${ }^{43}$ As Scheppele has argued, politics is no longer organized on a single left-right ideological axis in contemporary Western democracies. In the very least, a nativism-cosmopolitanism divide has strongly emerged as an additional, cross-cutting, axis for political alignment. ${ }^{44}$ When two major ideological axes are salient to voters, there are at least four stable party types (and concomitant 'voter types') that can broadly capture the worldviews and political preferences of most voters in such systems: on Scheppele's classification, for example, one should expect left-nativist parties, ${ }^{45}$ right-nativist parties, ${ }^{46}$ left-cosmopolitan parties, ${ }^{47}$ and right-cosmopolitan parties. ${ }^{48}$ With each new salient axis, new permutations give rise to the possibility of an even a larger number of voter types in search of distinctive political representation.

In any system that has more than one salient political axis, a two-party system simply cannot approximate to the broad political worldviews of major

41 John Gerring, "Ideology: A Definitional Analysis" (1997) 50:4 Political Research Quarterly 957 at 980.

42 Pradeep K Chhibber \& Rahul Verma, Ideology and Identity: The Changing Party Systems of India (Oxford: Oxford University Press, 2018) at 15.

43 Sartori, supra note 4.

44 Kim Lane Scheppele, “The Party’s Over” in Mark Graber, Sanford Levinson \& Mark V Tushnet, eds, Constitutional Democracy in Crisis? (Oxford: Oxford University Press, 2018) 495 at 513.

45 Such as the Spanish Podemos Party.

46 Such as the American Republican Party under Donald Trump's leadership.

47 Such as the Indian Congress Party under Sonia Gandhi's leadership.

48 Such as the British Conservative Party under David Cameron's leadership. 
voter types. A regime will establish 'the rule of the people' only if it facilitates the representation of the preferences of every major voter type in its party system, with two caveats: first, as I will argue later in this article, it is legitimate — albeit sometimes unwise - to restrict the likelihood of political representation - or, at least, the likelihood of political success - of factional voters who do not accept that a democracy is the rule of all the people, even if a factional-inclusivist axis has become salient in that polity. Just as I cannot rely on my autonomy to sell my children or my (future) self into slavery, rule of all the people cannot be relied upon to transform a democracy into the rule of some of the people. Neither autonomy nor democracy are fully transparent values in this sense. ${ }^{49}$

The second caveat is that there is a feasibility limit to the total number of serious parties that a democracy can accommodate. A serious political party is a party that is, well, serious about seeking power or influence in a polity. Joke parties that contest elections for other motives or simply to cock a snook at 'the system', those that are likely to be themselves surprised if they end up winning, are not 'serious'. It is true that larger the number of distinctive parties in a system, smaller the political participation costs are likely to be for a voter. In fact, if there is a party that mirrors every voter's customized set of political preferences, political participation costs will be non-existent for every voter. Needless to say, such single-member 'parties' won't be parties in any meaningful sense. Furthermore, even as they reduce political participation costs, a large number of parties significantly increases voters' information costs. A voter who has to go through a list of fifty candidates belonging to fifty different serious parties is able to make an informed choice only after putting in considerable effort to educate herself on the distinctive ideological commitments and political platforms of all these fifty parties. She might as well focus her research on the fifty individual candidates in such cases (which would not be any less daunting, in any case). Too many choices may not matter when the stakes are low — such as when one is ordering a meal from a restaurant's menu — for one can make a legitimate choice having considered only the first five options. But when the stakes are as

49 Contrast them with freedom of expression, which is fully transparent in that it includes my freedom to remain silent. 
high as entrusting the government of one's polity, the voters' information costs must be reasonable enough to enable a judicious voter to consider the pros and cons of all candidates.

The sum of these concerns is the 'party system optimality principle': in contemporary democratic polities which divide along multiple salient axes, party systems should be optimised such that the total number of serious political parties is large enough to broadly represent every major 'voter type', but not so large that the information costs on judicious voters are too high.

\section{The Party-State Separation Principle}

The third constitutional principle in relation to parties is that a state should seek to ensure a separation of the ruling party/coalition and the state, so as to allow a genuine hope for today's losers to be tomorrow's winners. We will call this the 'party-state separation principle'. The basic argument is that if a party (usually the ruling party/coalition) becomes entrenched in the apparatus of the state, the political participation costs of the supporters of all other parties become insurmountable. The party-state separation principle demands a recognition of a host of opposition rights: including a significant opposition voice - perhaps even a veto - in constitutional amendments and constitutional appointments. It requires the bureaucracy, police, prosecution, judiciary, and fourth branch institutions to function in a non-partisan manner. The principle also demands equity - although, not necessarily equality — in state benefits given to the ruling party/coalition and to opposition parties. Recognising this principle is especially important given the salience of the institutional 'separation of powers' principle in constitutional theory - given how partisan loyalties can scramble institutional separation, it is essential that the party-state separation principle is considered alongside the institutional separation of powers principle, and given the same weight in constitutional thought.

The party-state separation principle requires that a state should preserve the genuine likelihood of different parties securing governmental power at different points in time. The transfer of power following elections should be peaceful, and the political opposition must be able to plausibly imagine itself as a government 
in waiting. It should therefore be hostile to a one-party system (where only one party is allowed to exist, de jure and de facto), or a hegemonic party system (where smaller parties are allowed to exist, but the system de facto and de jure favours a hegemonic party which remains in power) at all times. ${ }^{50}$ It should even be hostile to the kind of two-party system in which the two parties operate like a cartel, and make it structurally difficult for a third party to emerge. ${ }^{51}$ Any such fusion of parties and the state is not only bad for democracy, it is also likely to make the regime unstable because any significant voter type without mainstream political representation is likely to find solace in anti-system parties. On the other hand, the party-state separation principle is compatible with a predominant party system, where a single party or coalition de facto dominates all others, although de jure the system permits free and fair political competition and gives no structural advantage to the predominant party. That said, the purposive autonomy principle would still view a predominant party system as non-ideal, and seek to enable opposition parties to rise and flourish in such a system. Even if the opposition does not win elections, a robust opposition is essential to check the political power of the ruling party/coalition, and to reduce the four democratic costs effectively. Recall that these costs remain high in a system with only one healthy political party.

\section{The Anti-Faction Principle}

We can now consider the final principle. We must accept that an elected democratic government is unlikely to represent all the people of a state at any one given time, where representation is understood in terms of voters' electoral preferences as expressed on the ballot. But it does not follow that we should also

50 On party systems, see Zim Nwokora \& Riccardo Pelizzo, "Sartori Reconsidered: Toward a New Predominant Party System” (2014) 62:4 Political Studies 824 at 833.

51 Issacharoff and Pildes show how the two main parties have created an effective political duopoly in the United States: Issacharoff \& Pildes, supra note 33 at 644. Katz and Mair argue that the phenomenon of cartelization extends to Europe as well: Richard S Katz \& Peter Mair, "The Cartel Party Thesis: A Restatement” (2009) 7:4 Perspectives on Politics 753. 
accept that such an under-representative government only needs to serve the interests of those it represents. An under-representative government can, and should, still aspire to serve the interests of all its people. Parties, in their idealized sense, work towards the flourishing of all the people of their state; factions care only for a sub-section thereof. ${ }^{52}$ Parties are committed to the common good, factions are not. ${ }^{53}$ Factions a priori exclude the interests of their disfavoured section of the people even from being considered when framing policies - if these interests are considered at all, it is with a view to hurt them rather than to advance them. Importantly, given our capacity to threaten the very survival of humanity, at least in our times, factions would include parties that do not count the interests of the future people as legitimate concerns for their political calculations.

Factions fail to reduce the policy packaging costs for state institutions. We have seen that one of the key functions of political parties is to package the interests of all voters based on the party's value commitments. These policy packages are then tested in elections, and voters express their preferences for or against such packages, which information is then available to state institutions when framing policy. In the process, parties also translate any voter's factional interests into a subset of the common good through their policy packaging function, thereby moderating them to make them compatible with the interests of other citizens. Factions fail to do so. They also increase the political participation costs of the excluded voters - it is one thing to not have every party reflect one's voter type, quite another to have a party in a system not even consider one's interests as legitimate and relevant alongside the interests of all others. 52 It should be obvious that I am not speaking of infighting 'factions' within
parties.

53 Barber characterises factions as "sectarian parties": Barber, supra note 16 at 168. For a brief historical overview of the development of the conceptual distinction between parties and factions, see Bonotti, supra note 27 at 103-105. 
This distinction between a party and a faction has been long recognized in political theory. ${ }^{54}$ As Sartori put it, "[i]f a party is not a part capable of governing for the sake of the whole, that is, in view of a general interest, then it does not differ from a faction. Although a party only represents a part, this part must take a non-partial approach to the whole". ${ }^{55}$ Factions are concerned with the interests and well-being of only a sub-section of the people. Parties, even when they make claims on behalf of particular groups, "must transcend the language of particularity and re-articulate the claims they represent in such a way that their demand for a share in political power is justified to the entire people and not only to that particular group of individuals that chooses to associate with them" ${ }^{56}$ The point of the distinction is normative rather than taxonomical: "[it] is very likely that the empirical analysis of existing practices will show how parties and factions are often entangled, with different political agents exhibiting features of both, to a greater or lesser extent" ${ }^{77}$ It is important to note that the distinction attaches itself to the entity as a whole, and not to its individual actions. A party may have distinct policies catering to the interests of different sub-sections of the people - it will be a faction only if, taken as a whole, its political ideology and its policy platform is not justifiable to all the people. Admittedly, any attempt to distinguish real-world parties from factions too sharply is likely to fail. Having said that, Rosenblum is probably right when she suggests that, even as an empirical matter, "[w] here it is an original identity, or at least not reducible to prior political identities, the "we" of partisanship is more inclusive than other political identities". ${ }^{58}$

'Rule of the people' demands not only that political power is exercised by the people's representatives, but also that it is exercised in the name of all the

54 Jonathan White \& Lea Ypi, The Meaning of Partisanship (Oxford: Oxford University Press, 2016) at 32.

55 Sartori, supra note 4 at 50.

56 White \& Ypi, supra note 54 at 34.

57 Ibid.

58 Nancy L Rosenblum, On the Side of Angels: An Appreciation of Parties and Partisanship (Princeton: Princeton University Press, 2010) at 356. 
people. In the words of White and Ypi, "[t]he very ideal of collective self-rule implies that power is considered legitimate to the extent that it is justified to the whole people". ${ }^{59}$ It is this normative ideal which leads us to our final constitutional principle: that a state should seek to ensure that political parties do not operate as factions. We will call this the 'anti-faction principle', and amend White and Ypi's formulation somewhat to suggest that it requires political parties to ensure that their policies are objectively justifiable (rather than subjectively justified) to all the people. The amendment is required because it may be that a party fails to even communicate, let alone actually justify, its policies to all the people. So long as its policies are justifiable to all of them, the anti-faction principle should be satisfied. The anti-faction principle, therefore, does not require parties to articulate their policies in Rawlsian 'public reason' terms. ${ }^{60}$ Furthermore, a justifiability-standard is more tolerant of parties appealing strategically to particular sub-sections of the people as a matter of electoral tactics - so long as their policy platforms are nonetheless justifiable to all the people. Other independent moral and political constraints no doubt exist - such strategic appeals should not demonize any other section of the people, for example.

Unlike the purposive autonomy principle, which frowns upon single-issue parties, the anti-faction principle - on its own - does not require parties to have a plenary policy package. An anti-corruption party is not a faction. The party's size doesn't matter either. A small Green Party is likely to be a party, since its environmental objectives are justifiable to all. Even a party whose entire policy platform is devoted to advantaging a single societal group may not necessarily be a faction. A Workers' Party, a Dalit Party in India (for former 'untouchable' castes), or an African-American Party in the US can be parties, if they can justify the interests of their preferred groups by reference to the general interest (for example, that historically excluded groups have a greater claim on the state's resources). Furthermore, parties are allowed to make ideological and policy

59 White \& Ypi, supra note 54 at 34 [emphasis in original].

60 John Rawls, “The Idea of Public Reason Revisited” (1997) 64:3 University of Chicago Law Review 765. 
mistakes - the anti-faction principle does not demand that their policies actually work. But it does demand sincerity and plausibility — some obviously unworkable or implausible policies may evidence lack of sincerity. A party that continues to deny human impact on global environment and its potential implications for future people, despite all the evidence to the contrary, is probably a faction because it is refusing to consider the interests of the future people, and its policies are unlikely to be justifiable to them. The one exception to the sincerity and plausibility test is this: even if a 'party' sincerely believes that the only interests that count are the interests of a sub-section of the people rather than those of all the people, its sincere rejection of democracy as rule-of-all-thepeople is not enough to dodge its characterization as a faction.

The absence of a bright line dividing parties from factions may especially bother legal scholars: as our discussion of a preference for second order regulation will shortly demonstrate, their fears are unfounded. The proposed regulatory architecture would never require a court to decide whether a defendant before it is a genuine party or a faction.

\section{The Contours of Moderated Parliamentarism}

As constitutional principles, the principles discussed in the preceding parts are primarily addressed to the framers (and changers) of constitutions, who should consider them alongside numerous other relevant principles, their political context, historical path dependencies, and so on. An all-things-considered judgment in particular contexts may legitimately reject design preferences derived from acontextual first principles. Furthermore, few democracies have the option of starting with a clean slate - existing design structures create path dependencies: it is often better to change a long-standing existing system incrementally than to impose some theoretically optimal model through radical reform. Context and history are key ingredients in constitutional design, so a general conceptual article can do little more than indicate the likelihood that certain design combinations will further or detract from a given set of normative principles. 
With these limitations of the current project in mind, let us consider if these principles have any general implications for the design of key partisan constitutional institutions (i.e. the political executive and the legislature). The first thing to note is that the four aforementioned principles can come into tension with each other. The anti-faction principle demands that constitutional architecture should disincentivize factions - however, if it does so for a faction that represents a salient voter type in a deeply divided society, the party system optimality principle will be compromised. The party-state separation principle sometimes requires curtailing the autonomy of the ruling party/coalition. A wise constitution maker will not seek to maximise any of these principles, for doing so will almost certainly be at the cost of another one of these principles (or, for that matter, other principles that we should care about). What we need to find is a Goldilocks zone of optimality, where we can sufficiently respect each of these important norms.

Secondly, the constitutional principles we canvassed in the previous part have implications for many aspects of constitutional design, and not just what the political executive and the legislature might look like. These other implications include campaign finance regulation, antidiscrimination regulation, design of the fourth branch, protection of opposition rights, and so on. By focussing on the design of the key institutions of the partisan state in this article, I do not wish to imply that the force of the principles is spent once the shape of the two key political institutions is settled.

Finally, we should note that the need to protect purposive autonomy of parties dictates not only a cautious approach to imposing duties on parties, but also how any duties may be imposed. Duty-imposing norms should be crafted so as to not destroy the dual character of parties. In general, and subject to their effectiveness in a given context, three broad regulatory criteria should govern design possibilities for duty-imposing norms with respect to political parties:

- Political enforcement and self-regulation are better than judicial enforcement, ${ }^{61}$

61 Khaitan, "Constitutional Directives", supra note 31. 
- Nudges are better than command-and-control, ${ }^{62}$ and

- Carrots are better than sticks. ${ }^{63}$

These criteria are partial to 'second-order regulation', which emphasizes the importance of 'background competitive structures' that shape decision-making, rather than seeking to police behaviour directly through first-order commands. ${ }^{64}$ Note that all background institutional structures shape the behaviour of actors who inhabit them - the question is not so much whether to have second-order regulation, but what type of second-order regulation is worth having. For example, a democracy has to choose some electoral system, and each system shapes the behaviour of politicians differently. Many regulatory objectives in relation to parties can be achieved by attending to achieving the right combination of institutional design of elected state bodies and the manner in which they are constituted in partisan elections. Indirect, second-order, regulation is generally more conducive to party autonomy than first-order legal regulation.

\section{A. Mapping Regime Type and Electoral Systems}

Before I move to defend moderated parlimentarism, a brief overview of the key options available to the designers of the political executive and the legislature is helpful. There are three key institutional variables for classifying the main modes of organising representative power in democracies:

1. whether the political executive and/or the legislature are unified/unicameral or divided/multicameral;

2. what is relationship between the president and the premier in a divided executive, and between the several chambers in a multicameral legislature; and

62 Cass R Sunstein, "Nudging: A Very Short Guide” (2014) 37:4 Journal of Consumer Policy 583.

63 In other words, it is better to ensure compliance by making the realization of some regulatory principles a precondition to accessing state support for parties, rather than through penalties.

64 Issacharoff \& Pildes, supra note 33 at 647. 
3. what is the relationship between the political executive (or a part thereof, if divided) and the legislature (or a part thereof, if multicameral).

Presidential systems (e.g. the US) have a unitary political executive elected directly by the people. Its survival is temporally fixed and does not depend on whether the legislature has confidence in it. Semi-presidential systems (e.g. Sri Lanka) have a divided political executive - typically a president and a prime minister. The relationship between the two is variable, institutionally as well as politically, although the president is typically superior to the premier institutionally. In such systems, the president is elected by the people in direct elections, and the prime minister is appointed (usually by the president) but must enjoy the confidence of the legislature (or a part thereof). Semi-presidential systems can be further divided into two sub-types: 'premier-presidentialism' systems do not allow the president to fire the prime minister (Sri Lanka between the 19th and 20th amendments), but 'president-parliamentarism' systems do (Sri Lanka after the 20th amendment). ${ }^{65}$ In parliamentary systems, the legislature (or a part thereof) does have the institutional power to fire the prime minister at will through a vote of no confidence. ${ }^{66}$

All of these systems are compatible with a unicameral legislature or a multicameral one. New Zealand's parliament is unicameral, India's is bicameral.

65 See Thomas Sedelius \& Jonas Linde, "Unravelling Semi-Presidentialism: Democracy and Government Performance in Four Distinct Regime Types" (2017) 25:1 Democratization 136 for the distinction. The labels that they assign to the sub-types are confusing, but retained here because of the currency they have gained in the literature.

66 A no confidence vote is distinct from impeachment: the former typically requires a simple majority to be passed and need not be based on any bad behaviour on the part of the premier; impeachment usually requires a supermajority and must be based on some specific bad conduct. Germany employs the constructive vote of no confidence, which allows parliament to withdraw confidence from a head of government, but only if there is a positive majority for a successor government. Although still easier to secure than an impeachment, it grants more political security to a premier than a parliamentary system with a simple vote of no confidence. 
In some bicameral systems, both houses are directly elected by the people (e.g. in the US), in others one is elected directly and another indirectly (e.g. in India); in others still, one chamber may be directly elected while the other appointed (e.g. in the UK). The two houses may have roughly co-equal legislative powers (e.g. the US) or one chamber may have greater legislative powers than the other (e.g. India).

Ganghof has recently added a new model to the matrix for organising executive-legislative relations: 'semi-parliamentarism'. This type of system is a mirror image of a semi-presidential system. Instead of dividing the political executive leadership, "a semi-parliamentary system divides the assembly into two (roughly) equally legitimate parts, only one of which possesses the power to dismiss the prime minister in a no-confidence vote. It establishes a formal separation of power between the executive and one part of the assembly". ${ }^{67}$ Given this definition, New Zealand — with its unicameral legislature — is a parliamentary system rather than a semi-parliamentary one. But the United Kingdom and Canada do not qualify as semi-parliamentary either: although they are bicameral, their second chamber is largely or entirely appointed. Neither does India, which has a second chamber that is indirectly elected by provincial legislatures. These are all parliamentary systems, because their second chambers lack sufficient democratic legitimacy to effectively and adequately check the government and the confidence chamber. Australia, on the other hand, has two directly elected chambers, only one of which has the power to remove the government from office - it therefore qualifies as a semi-parliamentary system. The Indian example should, however, alert us to the fact that the distinction between parliamentary and semi-parliamentary regimes may well be one of degree — an indirectly elected chamber still has some democratic legitimacy, and is best placed half-way between these two regime types. On the other hand, even in semi-parliamentary systems with two elected houses, it is important to avoid a legitimacy tie between the two houses. Such ties can muddle the design

67 Steffen Ganghof, “Australian Bicameralism As Semi-Parliamentarism: Patterns of Majority Formation in 29 Democracies" (2018) 53:2 Australian Journal of Political Science 211 at 212. 
imperative of reserving the confidence-supplying function for one chamber alone. A well-designed semi-parliamentary system would ensure that the checking and appointing chamber has sufficient democratic legitimacy to effectively check the government and the confidence chamber, but not enough to threaten the survival of the government itself — if that happens, the checking and appointing chamber would effectively transform itself into a second confidence chamber. Thus, it is important to finely calibrate the democratic legitimacy of the checking and appointing chamber in a semi-parliamentary regime - close enough to that of the confidence chamber, but just a step behind to not usurp the latter's confidence function. Hence the importance of Ganghof's qualification that their legitimacy must only be roughly equal.

All of these permutations can be replicated or reconfigured at the federal, provincial, or local level, depending on the number of layers of political government in the state. The table below summarises the key features of the various key models: ${ }^{68}$

\begin{tabular}{|l|c|c|c|}
\hline & $\begin{array}{c}\text { Political Executive: } \\
\text { United or Divided }\end{array}$ & $\begin{array}{c}\text { Legislature: } \\
\text { Unicameral or } \\
\text { multicameral }\end{array}$ & $\begin{array}{c}\text { Who can fire the } \\
\text { premier? }\end{array}$ \\
\hline Presidentialism & United & Either & No premier exists \\
\hline Parliamentarism & United & Either & $\begin{array}{c}\text { Legislature (or part } \\
\text { thereof) }\end{array}$ \\
\hline $\begin{array}{l}\text { Premier- } \\
\text { presidentialism }\end{array}$ & Divided & Either & $\begin{array}{c}\text { Legislature (or part } \\
\text { thereof) }\end{array}$ \\
\hline $\begin{array}{l}\text { President- } \\
\text { parliamentarism }\end{array}$ & Divided & Either & $\begin{array}{c}\text { President and } \\
\text { Legislature (or part } \\
\text { thereof) }\end{array}$ \\
\hline $\begin{array}{l}\text { Semi- } \\
\text { parliamentarism }\end{array}$ & United & Bicameral & $\begin{array}{c}\text { One (of two) legislative } \\
\text { chambers }\end{array}$ \\
\hline
\end{tabular}

68 These models are far comprehensive. South Africa, for example, does not neatly fit into any of these models. 
These choices ought not to be made without simultaneously considering their relationship with different available options for the choice of electoral system. One of the key takeaways of this article is that in order to take parties and party systems seriously, constitutions must not retrofit electoral system choices to a specific executive-legislature design chosen ex ante. Rather, both choices must be made alongside each other, after careful consideration of their mutual impact on each other. So, here are the broad possibilities available with respect to the electoral system. Note that for every office or institution constituted through direct elections, a different electoral system can be applied. Thus, there is a mind-bogglingly large number of ways in which different electoral systems can be designed. An overly simplistic map of most of these systems can be drawn by teasing out four key variables: ${ }^{69}$

1. the district magnitude (single-member, multi-member, or at large);

2. the object(s) of voter choice (candidate, party, or both);

3. the ballot structure (categorical or dividual, cardinal or preferential); and

4. the electoral schedule (simultaneous or asynchronous, staggered or wholesale).

District magnitude concerns the number of constituencies into which the electors for an office or institution are distributed. They can range from singlemember districts which elect a single candidate for an assembly at one end of the spectrum (as in British parliamentary elections) to the entire electorate constituting one national district (e.g. Israel) - with multi-member districts of various sizes (e.g. Ireland) in between. So, in order to elect a 200-member assembly, single-member districts will require 200 constituencies electing one candidate each, five-member districts will need a total of 40 electoral districts electing 5 candidates each, and an at-large election will have a single national constituency electing all 200 members. In general, larger the district magnitude,

69 Much of the discussion that follows - excepting the variable concerning electoral schedules — is drawn from Michael Gallagher \& Paul Mitchell, "Dimensions of Variations in Electoral Systems" in Herron, Pekkanen \& Shugart, eds, supra note 18 at 23. 
the more proportionate the relation between votes and seats is likely to be thus, when the entire electorate forms a single electoral district, the votes to seats translation will be most proportionate. When the electorate is divided into fivemember constituencies, the outcome is likely to be more proportionate than if it were divided into single-member constituencies. So, district magnitude is directly related to the proportionality of the election.

The object of a voter's choice could be individual candidates, or political parties, or both. In some systems, a voter casts her votes for candidates directly (usually, but not necessarily, affiliated to a party); in others for a party directly. Some systems (e.g. New Zealand or Germany) allow each voter to cast two votes: one for an individual candidate and another for a particular party. Even in systems where voters cast only one vote for a candidate, the system can 'count' it twice if it adjusts the final seat distribution in the assembly by allocating additional seats based on the aggregate votes received by each party (through their candidates) in order to reduce disproportionality.

Third, a ballot can be structured along two distinct classifications. On the one hand, a ballot can either be categorical, where the voter simply votes for an individual candidate or a party, or dividual, in which a voter may/must split her vote among several candidates. For example, in a five-member constituency, a dividual ballot may allow each voter five votes, which may be cast for five different candidates, or all five for the same candidate, or distributed between two candidates and so on. While a categorical ballot will always be cardinal, a dividual ballot may be cardinal or ordinal. A dividual ordinal ballot can allow/require a voter to express her preference for any, some, or all candidates/parties by ranking them in order of preference (i.e. a preferential vote or ranked-choice vote); in a dividual cardinal ballot she may be permitted to mark all the candidates she approves of, but without ranking them (i.e. cast an approval vote $)^{70}$ or distribute a fixed number of voting 'points' or fractions — say

70 For details of approval voting, see George Tsebelis, "How Can We Keep Direct Democracy and Avoid 'Kolotoumba”' (2018) 35:1-2 Homo Oeconomicus 81. 
five vote points or one-fifths of her vote - between any number of candidates (through a cumulative vote). ${ }^{71}$

Finally, electoral schedules can be organised in various ways. Different state institutions or offices that are constituted through direct elections may go to polls simultaneously (and, therefore potentially impact each other) or asynchronously (where this mutual impact is arguably lesser). An assembly can be elected in a staggered manner, where a fraction of its membership is elected every few years, or it may be reconstituted wholesale after each term. Elections to the same institution or office may be held on a single day, or over a period of few weeks (sometimes, even months). Finally, elections schedules may be fixed and predictable, or variable and unpredictable or determined by the incumbents.

There are other dimensions of variations which we will avoid discussing here. The possible ways in which just these four dimensions can be combined are numerous. How each of these permutations might combine with the possibilities of institutional design of the legislature and the political executive makes things even more complicated. A president can be directly elected based on a single, national, constituency or through multiple constituencies (such as the electoral college system in the US). The unenviable task of constitution makers is to combine these variables - within political constraints and path dependencies - in ways that optimise not only the four constitutional principles in relation to parties, but also result in an institutional set-up that is best-suited to all other purposes the constitution has set out to achieve!

\section{B. Moderated Parliamentarism}

Mercifully, our task here is more manageable. In the rest of this part, I will outline a particular version of semi-parliamentarism, and then defend it as an attractive way to optimize our four constitutional principles. The claim is not

71 On cumulative voting generally, see Richard L Engstrom, Delbert A Taebel \& Richard L Cole, "Cumulative Voting as a Remedy for Minority Vote Dilution: The Case of Alamogordo, New Mexico” (1989) 5:3 Journal of Law \& Politics 469. 
that it is the only defensible way - that would require a consideration of all possibilities in this high-population field of options. And we aren't even considering the constraints and path-dependencies imposed by particular histories and contexts. By necessity, therefore, my theoretical claim has to be a modest one. The specific version of semi-parliamentarism I will defend has several distinctive features: mixed bicameralism, moderated (but distinct) electoral systems for each chamber, weighted multipartisanship, asynchronous electoral schedules, and deadlock resolution through conference committees. We can call this version moderated parliamentarism. ${ }^{72}$

\section{Semi-Parliamentarism}

Like all semi-parliamentary systems, moderated parliamentarism has two directly elected chambers with distinctive functions. ${ }^{73}$ Only one of these chambers, the confidence and opposition chamber has the power to dismiss the prime minister at will. The function of this chamber is to supply confidence to the political executive, which itself must be drawn entirely from within its own ranks. While this chamber also performs a checking function, it will tend to do so with material — as opposed to 'merely' expressive - consequences only in politically extraordinary circumstances, i.e. when the government's majority is

72 Readers will note that many features of moderated parliamentarism can be seen in the Australian system. Even so, there are important distinctions: the composition of the Australian senate is scrambled by federalism and the adoption of a complicated version of single-transferable-vote. Further differences relate to electoral schedules, dispute resolution mechanisms and so on. The extent to which these differences matter is a task for another day.

73 Russell argued that the traditional political science distinction between weak and strong bicameralism along the axes of symmetry of powers and congruence of partisan composition is insufficient to capture the de facto functioning of the system, and that a third dimension of "perceived legitimacy" is essential to consider: Meg Russell, "Rethinking Bicameral Strength: A Three-Dimensional Approach" (2013) 19:3 The Journal of Legislative Studies 370. While a requirement of direct elections is neither necessary nor sufficient for a political institution being perceived to be legitimate, it is a good rough indicator, at least for an acontextual, theoretical, argument like this one. 
in doubt (say, due to a brewing rebellion against the leadership within the ruling party). To put the point differently, the confidence function itself is a specific type of checking function: it is not deployed during ordinary legislative business, but the threat of the loss of confidence exerts checking pressures on the government of the day - usually through the mediation of the party, the political executive knows how far it can push its party members in the confidence chamber without losing support. Thus, the confidence chamber ensures that the ruling party/coalition is able to exercise a continuous check on the political executive.

Another, often-ignored, dimension of a confidence and opposition chamber is its opposition function. ${ }^{74}$ Normally, the political opposition in such a chamber lacks the power to fire the government, because it does not control the chamber. But it does exercise considerable influence: a tactful opposition knows that it only needs to break away enough legislators from the ruling party/coalition to topple a government. More importantly, well-functioning confidence and opposition chambers allow the political opposition to hold the government discursively accountable. The opposition parties in the confidence and opposition chamber share this checking function with the other chamber, about which more shortly. But because of their common checking function, and because all of them merit the rights and powers that moderated parliamentarism must guarantee to the opposition, references to 'opposition parties' in this article should be understood to include all legislative parties — in both chambers that do not form part of the political executive. The opposition members' right to speak freely, criticise the government and the ruling party/coalition, and seek accountability from ministries is an essential feature of parliamentary systems that must be fully preserved, nay strengthened, with constitutional safeguards in moderated parliamentarism. A sub-majority of members (say $40 \%$ of the

74 David Fontana, "Government in Opposition” (2009) 119:3 Yale Law Journal 548; Gregoire Weber, "Loyal Opposition and the Political Constitution" (2017) 37:2 Oxford Journal of Legal Studies 357; Sujit Choudhry, "Opposition Powers in Parliamentary Democracies" (2020) [unpublished, on file with author]. 
members in either chamber) or a significant opposition voice (say any three of the five largest parties in the checking and appointing chamber and the leader of the opposition in the confidence and opposition chamber) should be empowered to convene a session of a chamber, veto the end of a session, and set the agenda for some fraction of the chamber's business (say, one day every week). ${ }^{75}$ As the government in waiting, the leader of the opposition and the shadow cabinet also need to receive regular intelligence and national security briefings, and briefings from senior civil servants in the department they are shadowing, respectively (suitably subject to a confidentiality oath).

However, the largest opposition party (or alliance) in the confidence and opposition chamber has an additional function: to supply a government-inwaiting, i.e. a shadow cabinet, led by the constitutional office of the leader of the opposition. The role of this office is to channel criticism of the government's acts, omissions, ideology, and policies, to offer alternatives on each of these fronts, and to continuously communicate its criticisms and alternatives to the people. Unlike other opposition parties that can confine themselves to criticism, the shadow cabinet has to propose viable alternatives, if it is to inspire any confidence in its claim as the government-in-waiting. All necessary resources and protections must be guaranteed to the office to enable it to perform its key democratic function. As the government-in-waiting, the shadow cabinet's critical democratic function in constantly asking the government to justify publicly why it continues to deserve the confidence of the chamber should not be underestimated. If the government falls, it is the shadow cabinet's experience in opposition that enables it to form an effective government from day one.

The other chamber in moderated parliamentarism — the checking and appointing chamber - lacks the power to remove the political executive by

75 On sub-majority rules, see Adrian Vermeule, "Submajority Rules: Forcing Accountability upon Majorities" (2005) 13:1 The Journal of Political Philosophy 74. See also R (Miller) v Prime Minister, [2019] UKSC 41. Here the UK Supreme Court recognises the dangers of permitting the government to escape parliamentary scrutiny by relying on its agenda control and scheduling powers. 
withdrawing its confidence. The key functions of the checking and appointing chamber are - as its name suggests - (i) to check the political executive by seeking accountability from ministers, as well as by acting as a check on the legislative actions of the confidence and opposition chamber, and (ii) to make appointments to various constitutional offices of the state, especially senior offices of its fourth branch institutions such as electoral commissions. In order to discharge these functions effectively, the checking and appointing chamber must be sufficiently separated from the confidence and opposition chamber. 'Mixed bicameralism' achieves that to some degree, as we will shortly see. But further measures are necessary to ensure that the two chambers don't become mirror images of each other, each controlled by the political executive of the day - that would defeat the point of moderated parliamentarism. Two key measures of the separation of the two chambers, apart from mixed bicameralism are: (i) there should be an eligibility bar for a current or former member of the checking and appointing chamber to contest any partisan elections other than seeking re-election to the same chamber, and (ii) current or former members of the checking and appointing chamber should be ineligible for any appointments or perks that are within the gift of the political executive of the day. These features are essential to guarantee the independence of this chamber from the powerful political executive.

The checking function for legislative proposals is apt for a default simple majority based decision-making rule. ${ }^{76}$ Suitable deviations are advisable on key matters, such as super-majority rules for constitutional amendments and submajority rules for preliminary and procedural actions that allow opposition parties to "force public accountability and transparency upon majorities". ${ }^{77}$ At least in polities with more than one salient political axes, it is unlikely that any single party will have a working majority in the proportionately-elected checking and appointing chamber. The ruling party that dominates the confidence and opposition chamber may well be the largest party in the checking and

76 Kenneth May, "A Set of Independent Necessary and Sufficient Conditions for Simple Majority Decision” (1952) 20:4 Econometrica 680.

77 Vermeule, supra note 75 at 74. 
appointing chamber. Even so, ordinarily, it should still need to convince at least one or two other parties to support a legislative measure if it is to be enacted. Since high executive office will be reserved for members of the confidence and opposition chamber alone, the only consideration the ruling party or alliance can offer to these smaller parties in the proportional chamber in return for their support for legislative proposals is influence on policy (or appointments). Mixed bicameralism therefore incentivises policy-based shifting alliances between parties necessitated by the need for a majority in the checking chamber, forcing the ruling party to take at least a part of the opposition along on most legislative issues.

\section{Weighted Mulipartisanship}

On the other hand, the appointing function is best discharged through weighted multipartisanship, rather than through a simple majority rule. Constitutional appointments are best made by a committee of the checking and appointing chamber in which all parties above a threshold number of seats in the chamber have an equal voting strength. The goal is to give an equal say in appointments to the largest 3-7 parties that — together — represent the largest voter types in the polity (comprising at least $60 \%$ or so of the electorate). The precise thresholds can vary depending on the context: in highly fragmented polities, a larger number of parties (say, seven) need to be involved, whereas in less fragmented polities, vesting the appointment power in the three largest parties should suffice. The number of appointing parties should never be less than three, however: the process must be multipartisan, rather than bipartisan or unipartisan; furthermore, the voice of the eligible parties should be weighted to make them equal, rather than be proportionate to their seat share. There are, no doubt, other ways to ensure weighted multipartisanship in constitutional appointments. A quick note on judicial appointments: they may require special considerations, and a separate judicial appointments commission may well be desirable. Even so, any political voice in judicial appointments should still be organised according to the aforementioned weighted multipartisanship principle. 


\section{Mixed Bicameralism}

Moderated parliamentarism adopts mixed bicameralism in the sense that it seeks to accrue the benefits of both majoritarian as well as proportional electoral systems in its two distinctive chambers. There is no perfect electoral system because the two goals that elections must serve - representation of the people and constitution of stable and effective governments - pull in different directions. While proportional electoral systems better serve the need to represent all the people, majoritarian electoral systems are better at providing stable and effective governments. Some efforts have been made to combine their respective virtues in what are generally called mixed electoral systems. A mixed electoral system is one which simultaneously 'implements the two principles of representation' - plurality/majority and proportionality — in elections to a 'particular collective body'. ${ }^{78}$ There are many ways of mixing electoral systems, such as mixed-member proportional representation or parallel voting. Unlike mixed electoral systems, in mixed bicameralism the electoral systems remain (largely) distinct, but are applied respectively to the two chambers of a bicameral legislative. The mixing in mixed bicameralism takes place in the representative outcome in the legislature taken as a whole: the confidence and opposition chamber is elected using a single-member-constituencies based majoritarian system, while the checking and appointing chamber is elected through a proportional system based on multi-member or at-large constituencies. As Waldron says, since there is "virtue in arranging different bases of legislative representation in two assemblies", it is better to have two legislative chambers "rather than putting all one's eggs in one basket ... and trying to perfect a single scheme of legislative representation". ${ }^{79}$ Since there is no perfect electoral system for representation, a combination of two systems - via two assemblies elected

78 Michalak, supra note 18 at 94.

79 Waldron, supra note 16 at 76. See also William Riker, "The Justification of Bicameralism” (1992) 13:1 International Political Science Review 101. 
on different bases — are likely to complement each other and provide more optimal representation than a single assembly. ${ }^{80}$

\section{Moderated Electoral Systems}

Under moderated parliamentarism, the majoritarian electoral system used to constitute the confidence and opposition chamber as well as the proportional electoral system for the checking and appointing chamber are both moderated. The mechanism for moderation in each case is different, but they do not transform either system into a mixed electoral system. The most common mode of moderating the proportionality of a proportional electoral system (short of mixing it with elements of majoritarianism) is the use of electoral thresholds. Almost all proportional systems around the world moderate the proportionality of an exact translation of votes into seats in some manner. Requiring an electoral threshold — the minimum number of votes a party must win in order to secure any seats at all — mitigate the proportionality of the system somewhat. Without any thresholds, the total number of parties that win seats in the chamber can be extremely large.

While parties must be an object of voter choice, moderated parliamentarism is compatible with the electoral system being either 'closed list' (i.e. where voters vote for a party alone) and an 'open list' (where they may have at least some influence over the ordering of candidates on their preferred party's list). Moderated parliamentarism is also compatible with the checking and appointing chamber being elected from either an at-large constituency of the entire polity, or from several multi-member constituencies — so long as the size of these constituencies is sufficiently large. ${ }^{81}$ As we have already noted, district magnitude has a positive relationship with the proportionality of the outcomes

\section{Waldron, ibid at 77-78.}

81 Multi-member constituencies may be most appropriate for federal states, which often need to extend a federal dimension to the "upper chamber"; in federal polities, then, each province or state can count as one constituency. Assessment of any disproportionality introduced in the checking and appointing chamber to accommodate federalism is beyond the scope of this article. 
- larger the constituency district, more proportionate will the result be. However, systems like the single transferable vote get uncomfortably close to a mixed model, inasmuch as they can distract the voter too far from focussing on the party and pay too much attention to the individual candidates. ${ }^{82}$ The goal is to create a checking and appointing chamber that is largely (but not purely) proportional.

The majoritarianism of majoritarian electoral systems can also be mitigated, without adopting a mixed electoral system. The most commonly used majoritarian system — first-past-the-post system — adjudges the candidate or party with the most number of votes as the winner of an election. The system is described as 'majoritarian' because it is designed to squeeze out smaller parties, although it is very difficult for any candidate to secure an actual majority of the votes cast in a contest between more than two credible candidates. Very often, therefore, the winner of an election in a first-past-the-post majoritarian system only secures a plurality of the votes cast. This is what hurts minority parties (and minority voter types that they represent) — it is entirely possible for a minority party with geographically dispersed (rather than concentrated) popular support to secure $20 \%$ of the votes nationwide without winning a single seat in its legislature under first-past-the-post. It is also possible for the winning party to secure a simple majority of seats in the legislature with as little as $30 \%$ of the popular vote. The system over-translates the winner's vote-share into seat-share.

The main way to mitigate the majoritarianism of the first-past-the-post system - without opting for a mixed electoral system — is by changing its ballot structure from categorical to dividual. Forcing — or even permitting voters to favour more than one candidate reduces polarization and incentivises parties to build broader coalitions. A dividual ballot is normally used for multimember districts, but there is no reason why they cannot be employed in singlemember constituencies. Two forms are possible: a cardinal dividual ballot (approval vote) or an ordinal dividual ballot (ranked-choice or preferential vote). In

82 Marsh shows that a majority of Irish voters in single transferable vote elections were primarily candidate-centred. Michael Marsh, "Candidates or Parties?: Objects of Electoral Choice in Ireland” (2007) 13:4 Party Politics 500. 
a fully optional approval vote system, each voter is allowed to approve as many candidates as she thinks are electable. She may concentrate her approval in a single candidate, or two, or five. In a mandatory approval vote system, she may be required to approve at least (say) two candidates. In a limited optional approval vote system, she may be permitted to approve up to (say) four candidates. The candidate who secures the most votes wins.

An ordinal dividual ballot also permits a voter to vote for multiple candidates. However, unlike a cardinal dividual voting system, she can allocate different weights to her preference for different candidates. She must/may rank all/any/some (such as her top two) of the candidates in her order of preference. ${ }^{83}$ Only the first-ranked votes are counted in the first round. If no candidate crosses the $50 \%$ mark in the first round, the candidate with the least number of firstchoice votes is eliminated and the second-choice preferences of her voters is distributed to the other candidates. The process is repeated until one candidate crosses the $50 \%$ threshold, or only one candidate remains. A different way of counting is to eliminate all but the top two candidates after the first round and distribute the second-preference votes of all eliminated candidates to the two candidates still in the fray.

Whether cardinal or ordinal, both moderation techniques employing a dividual ballot have the same goal: of politically rewarding parties and candidates who are closer to the median voter. Because every voter has the same voting capacity, the egalitarian principle behind one-person-one-vote is not violated. The effect of either approach is to moderate the relatively harsher impact that first-past-the-post system has on minority voter-types. The dividual ballot system in single-member constituencies is still not proportionate, for minority parties would still fail to translate their votes into seats proportionately; winning parties are still likely to over-translate their votes into seats. But the majoritarianism of the first-past-the-post system is nonetheless moderated.

83 On preferential vote, see Benjamin Reilly, "Centripetalism and Electoral Moderation in Established Democracies” (2018) 24:2 Nationalism \& Ethnic Politics 201. 


\section{Asynchronous Electoral Schedules}

Finally, further systemic moderation is achieved, and a legitimacy tie is avoided, by adopting specific electoral schedules. Elections to the confidence and opposition chamber must be wholesale, given the nature of parliamentary systems. Because they can fire, and be fired by, the premier, the terms of the confidence and opposition chamber are also going to be variable (subject to a maximum limit). Holding the elections for the two chambers largely asynchronously rather than at the same time is likely to increase the moderation in the system - the qualification 'largely' permits some elections to take place simultaneously for feasibility reasons, but requires as much temporal separation between them as possible. The overall term of office for the legislators in the checking and appointing chamber should be longer (say, around six to ten years) than the maximum term of the confidence and opposition chamber (with an upper limit, say, between four and six years). A staggered electoral schedule for the checking and appointing chamber, with a fraction (rather than the whole) of its membership retiring every few years should further gear the system towards moderation. This combination of electoral schedules (longer, staggered, terms versus shorter, wholesale, renewal) must be organised in a manner that ensures that the confidence and opposition chamber, as a whole, always has a more recent mandate than the checking and appointing chamber. This way, a legitimacy tie between the two chambers can be avoided. The relative temporal freshness of the confidence and opposition chamber is important to ensure that the checking and appointing chamber does not seek to usurp its confidencesupplying role.

\section{Deadlock-Resolving Conference Committees}

While moderated parliamentarism avoids a legitimacy tie, it still opts for symmetrical legislative powers between the two chambers. This sets the system up for the possibility of a legislative impasse, thereby necessitating an efficient and party-conscious deadlock-resolution mechanism. A good mechanism to 
resolve a legislative deadlock — if a navette, ${ }^{84}$ i.e. the legislative shuttling of the proposal between the two houses, fails to resolve the matter - is through a party-conscious conference committee system. Conference committees are widely used to resolve differences between legislative chambers and facilitate a compromise solution. The conference committee mechanism may be designed in many ways, so long as it ensures that the ruling party/alliance needs secure the consent of some opposition parties in order to get the controversial legislation enacted. Here is one way such a committee may be designed under moderated parliamentarism: ${ }^{85}$ each house may nominate (say) ten members to a joint standing conference committee of the legislature. The confidence and opposition chamber's nominees represent the strength of the parties in the house proportionately. The checking and appointing chamber, on the other hand, nominates members in accordance with the weighted multipartisanship principle employed for constitutional appointments: it could send (say) two nominees from each of its five largest parties. What is important is that all major parties that represent a significant portion of the population in the chamber should be represented, and that the representation of parties from this chamber should be weighted to be equal rather than be proportional to their seat share. The joint committee may hammer out a compromise Bill by a majority vote of the combined membership (rather than through the unit rule — in which a majority of the members of each house must support the compromise, making a compromise harder to be achieved). Other measures that increase the likelihood of cross-partisan compromise may also be adopted: such as guaranteeing the secrecy of deliberations (at least for a limited period of time) and a bar on amendments to the conference committee proposals (such that each chamber can only accept or reject it). The awareness that the compromise proposal will still need to secure a simple majority in each house should

84 George Tsebelis \& Jeannette Money, Bicameralism (Cambridge: Cambridge University Press, 1997) at 55.

85 The model is based on the German conference committee system. See generally, ibid at 181 . 
constrain the outcomes the committee endorses. The likely compromise may not have consensus, but it will have to be multipartisan in order to be enacted.

Weighted multipartisan conference committees are an attractive mechanism for resolving institutional disagreements. No single opposition party, acting on its own, can bring the government's legislative business to a halt. So, deadlocks don't become a persistent feature of the polity — governments can still eke out legislative victories. But, unlike unmoderated parliamentarism, legislative victories are not normally guaranteed to governments in moderated parliamentarism. They can win only if they are politically nimble, and accommodate at least some opposition parties (even if these are different parties at different points in time). Opposition parties can veto a legislative proposal, but usually only by acting in concert. While the prospect of a legislative loss to the government is real, it is not catastrophic (i.e. a legislative defeat in the checking chamber does not signal a loss of confidence and, therefore, executive office). Moderated parliamentarism avoids both extremes of governmental dysfunction and regime instability associated with divided government under presidentialism, ${ }^{86}$ and unfettered government under unmoderated parliamentarism. ${ }^{87}$

86 Ginsburg \& Huq, supra note 1 at 176-86.

87 Scott Prasser, JR Nethercote \& Nicholas Aroney, eds, Upper Houses and the Problem of Elective Dictatorship (Perth: University of Western Australia Press, 2008). 
Once we combine the different features of moderated parliamentarism, the following picture emerges:

\begin{tabular}{|c|c|c|c|c|c|}
\hline & $\begin{array}{c}\text { District } \\
\text { Magnitude }\end{array}$ & $\begin{array}{c}\text { Object of } \\
\text { Voter } \\
\text { Choice }\end{array}$ & $\begin{array}{c}\text { Ballot } \\
\text { Structure }\end{array}$ & $\begin{array}{l}\text { Electoral } \\
\text { Schedule }\end{array}$ & $\begin{array}{l}\text { Deadlock } \\
\text { Resolution }\end{array}$ \\
\hline $\begin{array}{l}\text { Confidence } \\
\text { \& opposition } \\
\text { chamber }\end{array}$ & $\begin{array}{c}\text { Single- } \\
\text { member } \\
\text { constituencies }\end{array}$ & Candidate & Dividual & $\begin{array}{c}\text { Wholesale, } \\
\text { asynchronous, } \\
\text { Shorter \& } \\
\text { Variable Term }\end{array}$ & $\begin{array}{l}\text { Conference } \\
\text { committee }\end{array}$ \\
\hline $\begin{array}{l}\text { Checking \& } \\
\text { appointing } \\
\text { chamber }\end{array}$ & $\begin{array}{l}\text { Large multi- } \\
\text { member or at- } \\
\text { large } \\
\text { constituencies } \\
\text { (with } \\
\text { threshold) }\end{array}$ & $\begin{array}{c}\text { (Primarily) } \\
\text { Party }\end{array}$ & Categorical & $\begin{array}{l}\text { Staggered, } \\
\text { asynchronous, } \\
\text { Longer \& } \\
\text { Fixed Term }\end{array}$ & $\begin{array}{l}\text { Conference } \\
\text { committee }\end{array}$ \\
\hline
\end{tabular}

The intended effects of these features, in Lijphart's terminology, is to create a bicameral legislature that is incongruent and symmetric. ${ }^{88} \mathrm{~A}$ bicameral legislature is incongruent when the two chambers are likely to have different partisan makeups; ${ }^{89}$ moderated parliamentarism seeks to achieve partisan incongruence through the different electoral system and asynchronous electoral schedules, with staggered elections and longer terms for the checking and appointing chamber. Chambers are symmetric, on the other hand, if they have equal legislative powers. Moderated parliamentarism gives equal legislative powers to both chambers, and is therefore symmetric. Even so, it avoids a legitimacy ties between the chambers using temporal tools to justify vesting the confidence function in one of the two chambers alone. Furthermore, it greatly

88 Arend Lijphart, Patterns of Democracy (New Haven, CT: Yale University Press, 1999) at 198.

89 Cf. Tsebilis \& Money, supra note 84 at 53-54 who argue that even with partisan congruence, it is possible for two chambers to have non-identical preferences on some matters because of other factors. 
reduces the likelihood of an impasse through the multipartisan conference committee mechanism.

Readers can see that while moderated parliamentarism demands certain features, it leaves many design choices open. In particular, it is fairly ambivalent about the specific form of proportional representation that should be adopted for the second chamber - much will depend on the particular issues in the state concerned. A form of proportional representation that is desirable for a deeply divided country with a territorially concentrated minority population may not at all be suitable for a state where the main political division is ideological along a left-right spectrum, and dispersed more or less evenly across its territory. There may also be reasons to accommodate the federal character of the state in its checking and appointing chamber through multi-member constituencies mapping onto existing state boundaries. The dilution of the value of urban votes in majoritarian systems can also be compensated by extra representation for these areas in the checking chamber. ${ }^{90}$ In the rest of this article, I will argue that moderated parliamentarism is a good way to optimize the four constitutional principles we have identified in relation to political parties.

\section{In Defence of Moderated Parliamentarism}

Other things being equal, moderated parliamentarism is likely to better optimise all four of the constitutional principles in relation to political parties that we identified in Part III. In this part, we will see how.

\section{A. Purposive Autonomy Principle}

The purposive autonomy principle requires the design of the partisan state to be one that nurtures healthy parties and party systems, i.e. a system where most parties effectively perform their bidirectional and plenary intermediary function by keeping these four democratic costs relatively low: voters' information cost, political participation cost, policy packaging cost, and ally prediction cost.

90 On the dilution of the urban vote under majoritarianism, see Ran Hirschl, City, State: Constitutionalism and the Megacity (Oxford: Oxford University Press, 2020). 
Moderated parliamentarism facilitates the realisation of the purposive autonomy principle by enhancing the capacity of parties to enable them to perform their unique bidirectional intermediation function between the state and its people in five key ways.

First, the parliamentarism of the confidence and opposition chamber increases the likelihood that the link between the state and the people remains firmly routed through the political party. Although individual leaders may well reduce some of the transactional and informational costs associated with representative democracy, especially with the aid of social media, they are unlikely to be as efficient in doing so as a collective organisation like a party, at least not over an extended period of time. It is difficult, if not impossible, for an individual to have sufficiently developed plenary policy platform on all matters of governance.

The main difficulty with presidential regimes is that they allow presidents to compete with their parties for the intermediary function. In their influential book that comprehensively analyses data from all democracies between 1945 and 2007, Samuels and Shugart have shown that presidential systems are not ideal for nurturing a healthy party system. Their argument begins by noting that presidential and parliamentary regimes differ in two key respects: (i) the electoral incentives in parliamentarism are unified for the leader and her party - they sink and swim together. In presidentialism, these can, and often do, come apart. ${ }^{91}$ (ii) the guaranteed survival of the presidency for a fixed term means that there is little, if any, intraparty accountability of the leader to her colleagues, unlike in parliamentary regimes. Thus, the checks and balances that presidentialism secures across branches comes at the cost of their absence within the party. ${ }^{92}$ The impact of these differences, they argue, is that presidential systems are likely to see 'presidentialized' parties, whereas parliamentary systems

91 See also Nina Wiesehomeier \& Kenneth Benoit, "Presidents, Parties, and Policy Competition" (2009) 71:4 The Journal of Politics 1435.

92 David J Samuels \& Matthew S Shugart, Presidents, Parties, and Prime Minister: How the Separation of Powers Affects Party Organization and Behaviour (Cambridge: Cambridge University Press, 2010) at 15. 
are more likely to have 'parliamentarized' parties. The key difference between these two party-types is that in a parliamentarized party, the party is the principal and its leader is its agent; in a presidentialized party, that relationship is absent — instead, the leader has a significant degree of autonomy from the party. ${ }^{93}$ They admit that exceptions may exist such that we may witness presidentialized parties under parliamentarism, and vice versa - but they present evidence to show that these exceptions are "usually ephemeral ... because of the inescapable logic of such regimes". ${ }^{94}$ While individual charismatic prime ministers may seek to forge a direct, personal, link with the electorate, their vulnerability to the support of their parliamentary party ensures that the ruling party/coalition is more likely to remain more important to their survival in office than it is for a president in a presidential or a semi-presidential system. Parliamentary and semi-parliamentary systems do not split electoral accountability for governance between two different institutions: the confidence and opposition chamber, and the cabinet as its most powerful committee, remain the joint bearers of political accountability to the electorate. Their electoral fortunes sink or swim together. Samuels and Shugart argue that even in semi-presidential systems, although the Prime Minister may act as an agent of her party, the President "may be able to reverse the principal-agent relationship, making the prime minister an agent of the president rather than the party". ${ }^{5}$

Without passing an all-things-considered judgment on presidential and semi-presidential systems, we could tentatively conclude that to the extent they tilt the balance against party organization and in favour of individual party leaders, the purposive autonomy principle will be less keen on these systems. In order to be autonomous, parties ought to have considerable control over their members - especially its leaders - including the power to discipline and expel them. A weak party organisation, dominated by its leader, is likely to be too topheavy to effectively perform its bidirectional function as an intermediary between

\footnotetext{
$93 \quad$ Ibid at 16.

$94 \quad \mathrm{Ibid}$ at 18.

$95 \quad$ Ibid at 19.
} 
the state and the people. While it is true that Prime Ministers often act like Presidents, and there have no doubt been Presidents who are more ministerial in their functioning, the ability of a legislature to fire the executive leadership at will allows the ruling party or coalition to change the Prime Minister whenever the latter's interests diverge sufficiently from those of the party's. Furthermore, the role of parties between elections is likely to be different in presidential and parliamentary regimes. Presidentialized parties are more likely to ebb and flow, becoming active around elections and relatively dormant between elections by ceding the policy space to the government. Parliamentarized parties, on the other hand, are more likely to continue to function between elections, and are more likely to perform their bidirectional and plenary intermediary function continuously rather than cyclically. Thus, parliamentarism and semiparliamentarism - which allow the legislature (or a part thereof) to fire the top political executive leadership at will — are more likely to be conducive to the purposive autonomy principle.

The second feature highlights the superiority of moderated parliamentarism over pure parliamentarism. Pure parliamentary systems require the ruling party's internal rebellion to reach a critical mass before it affects the leadership. This feature means that as long as the number of internal dissenters remains under a threshold, the leadership can more or less ignore them, or indeed bully them into silence. While presidential systems can make the party largely irrelevant to president between elections, pure parliamentary systems allow powerful prime ministers to ignore below-threshold dissensions in the party ranks. Moderated parliamentarism corrects this weakness of the party vis-a-vis its leadership in pure parliamentarism through the checking and appointing chamber. The following features are designed to ensure the relative independence of the members of the ruling party in this chamber from the political executive (which is usually also the party leadership): relatively longer term of these members, asynchronous and staggered elections compared to those for the confidence and opposition chamber, and the ban on their candidature for any elections other than seeking re-election to the checking and appointing chamber. In effect, upon becoming a member of the checking and appointing chamber, a legislator 
can only nurse two political ambitions: continued membership of the same chamber through re-election or a political appointment within the gift of this chamber (rather than the political executive). These limited ambitions ensure that the partisan tie is retained. ${ }^{96}$ Legislators will remain accountable to the party in order to be successfully re-elected on the party ticket, but with somewhat greater protection from the political executive of the day than they might have under pure parliamentarism or other forms of semi-parliamentarism. At any rate, the key attraction of moderated parliamentarism is that the incongruent checking chamber — taken as a whole — is genuinely independent of the political executive. The fact that members of the ruling party in that chamber are still beholden to the party leadership is less of a problem because they are unlikely to hold a majority in the checking chamber. The checking function of the legislature is, therefore, made feasible without weakening the bond between the party and its legislators - a structure that optimises the centrality of the bidirectional intermediation function of political parties.

Third, single-member — and therefore smallish — constituency-based elections to the confidence and opposition chamber necessitate party structures to seep into the local level, allowing a closer connection between the party through its local representative - and the people. Unlike presidents, who can compete with their parties for the intermediary function, local members of parliament tend to have a symbiotic rather than a parasitic relationship with their parties — their political fates tend to be closely aligned such that — like prime ministers - they usually sink or swim together with their party. This allows for a representative model that strengthens, rather than weakens, the party's bidirectional intermediation role.

96 Julie VanDusky-Allen and Willian Heller argue that candidate selection under bicameralism tends to become centralised because party leaders seek coherence between the parliamentary parties in the two chambers: Julie VanDusky-Allen \& William B Heller, "Bicameralism and the Logic of Party Organization" (2014) 47:5 Comparative Political Studies 715. This is a strength, rather than a weakness, of moderated parliamentarism, which seeks to encourage strong, autonomous, parties capable of enforcing party discipline politically. 
Fourth, a dividual ballot for the election of the confidence and opposition chamber can reduce the policy packaging and ally prediction costs more effectively than a first-past-the-post ballot. A dividual ballot incentivises parties to build loose pre-electoral coalitions based on specific policy agreements. Smaller parties extract policy concessions from governance parties in return for advising their supporters to rank their larger ally as their number two choice or to approve the candidates of their larger ally. ${ }^{97}$ If some of the weight of interparty ally-identification and policy-packaging is moved prior to elections, these costs are likely to be even lower for the party or coalition in power, as well as for state institutions.

Finally, mixed bicameralism separates plenary governance parties — that are more likely to control the confidence and opposition chamber - from singleissue influence parties - that are more likely to exercise proportional influence in the checking and appointing chamber. This bifurcation permits some influence to single-issue parties, but incentivises plenary policy platforming by governance parties (i.e. parties that are serious about winning executive power). This feature of mixed bicameralism is likely to enhance the plenary intermediation role of parties better than many of its alternatives.

\section{B. The Party System Optimality Principle}

Moderated parliamentarism is good for party system optimality, which requires that party systems should be optimised such that the total number of serious political parties is large enough to broadly represent every major 'voter type', but not so large that the information costs on judicious voters are too high. Moderated parliamentarism is particularly apt at making a party system optimal. The mixed bicameralism of the system allows all above-threshold parties to be represented in the checking and appointing chamber. It is unlikely that any salient voter type will be left unrepresented in this chamber. Under a pure proportional system, lacking any threshold, the number of parties in the checking and appointing chamber can become so large that the voter

97 Reilly, supra note 83. 
information costs become unreasonably high. On the other hand, unlike a purely majoritarian system, smaller parties are unlikely to be squeezed out of the party system entirely. The power and influence they acquire in the checking and appointing chamber are meaningful enough to make these parties electorally sustainable. Furthermore, the moderation in the dividual ballot structure of the confidence and opposition chamber - by basing it on approval vote or preferential vote - also gives smaller parties considerable pre-electoral influence over the larger parties that are likely to dominate that chamber. ${ }^{98}$

On the other hand, the majoritarianism of the confidence and opposition chamber combined with the threshold in the checking and appointing chamber can ensure that the fragmentation of the party system does not go too far. A reasonably (but not very) high threshold is necessary to keep the voters' information costs low — the proliferation of a very large number of parties makes democracy difficult. Furthermore, too many parties fragment the polity excessively, such that the economies of scale that politics through parties affords start decreasing, thereby affective the citizens' political participation costs. Moderated parliamentarism is, therefore, committed to avoiding an artificial two-party system in a polity that is divided by more than one salient ideological axis, while at the same time ensuring that the system keeps a check on the total number of parties becoming too large. What is more, it seeks to realize this entirely though second-order regulation.

\section{The Party-State Separation Principle}

The party-state separation principle requires the state to ensure a separation of parties and the state. Unlike the other three principles, which are good for democracy, the party-state separation principle is essential to democratic functioning of any state. A system that permits the ruling party to entrench itself in state institutions is - definitionally — no longer a democracy. There are many features of moderated parliamentarism that facilitate the separation of the state and the ruling party/coalition. 
First, a key the supposed virtue of presidential regimes is that the separation of executive and legislative power ensures the possibility of two - rather than one - ruling parties, controlling different branches of the elected state. The main problem with a regime with two ruling parties — in opposition to each other rather than in coalition — is the possibility of a legitimacy tie. A democratic legitimacy tie between a directly elected president and a directly elected legislature is either going to result in an insurmountable - and, therefore, status-quoist — deadlock, or one institution - typically the presidency - asserting itself over the other (thereby changing the character of the regime into a sort of super-presidential system). ${ }^{99}$ The first possibility leads to a libertarian state, the second to an authoritarian one - as default, rather than considered, outcomes of institutional architecture, they are both undesirable. Like presidentialism, moderated parliamentarism also clips the wings of the ruling party/coalition significantly, but without creating destabilising legitimacy ties or irresolvable deadlocks.

Secondly, the incongruent (and, therefore, independent) checking and appointing chamber is a significant check on the ruling party and the political executive. Waldron's main caveat when defending what I have characterised as mixed bicameralism was that the second chamber must be functionally independent of the political executive. ${ }^{100}$ The point of the system is to ensure that the ruling party is unlikely to be able to dominate this chamber in the way that it might dominate the confidence and opposition chamber. Features such as staggered (as opposed to wholesale) elections to the checking and appointing chamber, and its asynchronous (rather than simultaneous) electoral schedule visà-vis the other chamber are designed to make it even less likely that the partisan

99 On super-presidentialism, see Michael S Fish, "The Executive Deception: Superpresidentialism and the Degradation of Russian Politics" in Valerie Sperling, ed, Building the Russian State: Institutional Crisis and the Quest for Democratic Governance (New York: Routledge, 2000) at 177.

100 Waldron, supra note 16 at 81-85. See also Nicholas Aroney \& Steve Thomas, "A House Divided: Does MMP Make an Upper House Unnecessary for New Zealand” (2012) 2012:3 New Zealand Law Review 403. 
makeup of the two chambers will mirror each other. ${ }^{101}$ Putting the point in more traditional institutional (rather than partisan) terms, Waldron argues that each house can check the other's abuse of power if both must concur to enact a legislation. ${ }^{102}$ Tsebelis and Money have shown that houses being forced into navette (shuttling) upon disagreement can itself have a considerable influence on legislative outcomes, even in contexts where the second chamber does not formally wield a veto. ${ }^{103}$ The joint conference committee mechanism in place if navette fails is especially useful for forcing the ruling party to a compromise position that is acceptable to at least some opposition parties. Independence of the checking and appointing chamber is also furthered by a lifetime bar on members of the checking and appointing chamber to be eligible for any partisan election other than a re-election to this chamber, as well as for any appointments or perks that are within the gift of the political executive of the day. In particular, because the prime minister must draw all her ministerial colleagues from the confidence and opposition chamber alone, she cannot dangle ministerial posts to secure long-term allies in the checking and appointing chamber. No doubt additional or alternative mechanisms to secure the independence of the checking and appointing chamber may be necessary in particular contexts.

Thirdly, although the need to avoid a legitimacy tie requires the confidence and opposition chamber to always have the most recent mandate, the conference committee mechanism for deadlock resolution does not afford either chamber the final say. As a form of parliamentarism, legislative initiative is likely — for most part — to remain with the ruling party or coalition. However, moderated parliamentarism requires the ruling party to secure the consent of at least some opposition parties in order to get its legislative business through; on the other

101 Bicameral legislatures with staggered electoral schedules are unlikely to affect the important of political parties in parliamentary systems generally: David M Willumsen, Christian Stecker \& Klaus H Goetz, "The Electoral Connection in Staggered Parliaments: Evidence from Australia, France, Germany and Japan” (2018) 57:3 European Journal of Political Research 759.

102 Waldron, supra note 16 at 78-80.

103 Tsebilis \& Money, supra note 84 at ch 6-7. 
hand, the likely multipartisan (rather than bipartisan) character of the checking chamber should ensure that the political opposition can block a governmental legislative proposal only if it opposes it in concert. In other words, moderated parliamentarism does not allow the winner to take all, but at the same time, does not make the winner's agenda to be held hostage to an intransigent opposition party. Complex political negotiations would still be necessary for the ruling party to prevail legislatively. Unlike the British system, where the Commons can institutionally override the Lords on most matters, ${ }^{104}$ under the proposed model, deadlocks between the two chambers are resolved politically rather than institutionally. Furthermore, unlike the US model, where the combination of a two-party system alongside a legislative process with three institutional veto players (the two houses and the President), moderated parliamentarism does not have an ideological tilt towards small-state libertarianism (which is what any system riddled with frequent and irresolvable institutional deadlocks is likely to come to embody).

Fourthly, moderated proportionality of the checking and appointing chamber ensures that there is no significant over-translation of votes into seats in this chamber. This is a further check on the power grab opportunity that a pure first-past-the-post system affords to the ruling party. Admittedly, the confidence and opposition chamber is indeed majoritarian, and will, therefore, overtranslate the votes of the ruling party/coalition into seats. For reasons we will shortly consider, this is necessary to check factionalism in the polity. But by ensuring a proportional checking and appointing chamber, a balance of sorts is achieved.

Finally, in moderated parliamentarism, appointments to key unelected constitutional offices (such as to the senior judiciary and fourth branch institutions such as electoral commissions) are made by the checking and appointing chamber - either directly on its own or through its weighted multipartisan appointing committee, with the consent of or consultation with other relevant stakeholders, where necessary. Oversight of non-judicial fourth

104 See Parliament Act 1911 (UK), $1 \& 2$ Geo V, c 13; Parliament Act 1949 (UK), $12,13 \& 14 \mathrm{Geo}$ VI, c 103. 
branch bodies is also the domain of a weighted multipartisan legislative committee. Given the proportional character of the checking and appointing chamber, it is unlikely to be dominated by any single political party. Furthermore, it makes appointment decisions through a process that overweighs the voice of the larger minority parties, rather than through a simple majority of members. This can be achieved by providing (say) the largest five parties in the chamber an equal vote in the appointments committee. Alternatively, (say) the five largest parties may each get to nominate candidates who may then be selected through a single transferable vote in the assembly. Whatever the chosen method, the idea is to avoid a simple majority rule that would allow the one or two dominant parties to make most appointments themselves. This is achieved by amplifying the voices of at least the larger of the small parties through weighted multipartisanship. It is important, however, that whatever decision-making process is selected does not give any party the power to prevent any appointment from being made - it is one thing to be given a voice in a decision, quite another to stall any decision on the matter entirely. Important constitutional offices cannot be left unoccupied because of intransigent veto players. Combined with the proportional character of the assembly, this mechanism should ensure that constitutional appointments are made jointly by all political parties that have won a significant measure of the democratic mandate, rather than by the majority party through a winner-takesall mechanism. The ruling party or coalition should find it a lot more difficult under these conditions to capture or compromise the autonomy of key constitutional offices.

\section{The Anti-Faction Principle}

The very nature of factions is such that they are at best indifferent to the interests of a part of the demos; at worst, they seek to exclude a part of the demos from the polity itself. They tend, therefore, to be polarising — voters that a faction seeks to exclude are overwhelmingly likely to detest it, whereas another group of voters may well like the faction precisely because of its hostility to the targeted group. No electoral system can effectively check a faction in a polity where the 
size of the hateful group far outweighs that of the hated group. ${ }^{105}$ Other constitutional measures, such as consociational guarantees, for the hated group may be necessary, even in a moderated parliamentary system.

In polities where factions do not have overwhelming popular support already, moderated parliamentarism incentivises parties to not act as factions. It seeks to moderate factions that represent a salient voter type by keeping them within the system, and affording them with some voice, while simultaneously ensuring that their access to power is limited. Moderated parliamentarism exerts a firm, but not overwhelming, centripetal force on the polity, moderating and, over time, eliminating factions. However, unlike the party-ban approach of some continental jurisdictions, moderated parliamentarism does not outlaw factions as a general matter. The feasibility and efficacy of ex post first-order regulations such as party bans in containing factions is questionable in any case. $^{106}$

The dividual vote system in the confidence and opposition chamber is likely to make it difficult for factions to win executive power. ${ }^{107}$ Polarising parties, like Marmite (a horrible-tasting British condiment that is inexplicably adored by some people), are either loved or hated. Under approval vote, factions will be disapproved by voters who hate them, but more tolerable centrist parties are likely to be approved even by voters who are only lukewarm in their support for them. Under preferential vote, factions are likely to be a voter's first choice, or last. In circumstances were no party is likely to secure $50 \%$ of the votes in the first count, a preferential vote system forces parties to vie not just for the rank one vote, but also enough rank two votes to win a contest. In other words, the dividual ballot forces parties to ask voters to at least tolerate them, even if they are not their first choice. This encourages parties to be broad churches, and to

\footnotetext{
105 Reilly, supra note 83 at 207.

106 Tom Gerard Daly \& Brian Christopher Jones, "Parties Versus Democracy: Addressing Today's Political-Party Threats to Democratic Rule” (2020) 18:2 International Journal of Constitutional Law 50.

107 Donald L Horowitz, "Where Have all the Parties Gone?” (2007) 133:1 Public Choice 13.
} 
speak to the interests of a larger group of people. Dividual ballots are, therefore, a key centripetal mechanism.

A dividual vote system is also a more sophisticated centripetal tool in comparison with the first-past-the-post system. It has been long recognised that a majoritarian system like first-past-the-post tends to move a polity towards a two-party system, by squeezing out smaller parties ('Duverger's Law'). ${ }^{108}$ But first-past-the-post is an unsophisticated tool that punishes all smaller parties indiscriminately by denying them power and influence. Ironically, the only small parties that are likely to flourish under first-past-the-post are factionalized parties that target geographically-concentrated ethnic groups. Reilly shows, however, that while preferential vote systems also deny executive power to smaller parties, they tend to confer significant influence on smaller parties that don't operate as factions. ${ }^{109}$ Essentially, parties like the Greens are able to advise their voters on which large party to put down as their second preference in return for policy deals reached with such parties. In addition, because factionalism is penalized by the system, larger parties are more likely to be reluctant to enter into similar deals with smaller factionalized parties like the Australian One Nation Party. Similar benefits should accrue under approval vote. Thus, a dividual ballot in a single member constituency not only distinguishes between governance parties and influence parties, it also privileges non-factional influence parties over factional ones.

That said, the dividual ballot has its limitations. Even as it distinguishes between the Greens and One Nation Party, this system does not distinguish between a hateful dominant group party seeking to exclude a minority, and a party for a hated minority group seeking inclusion. Both types of parties are likely to suffer in a dividual ballot, even though only the former will qualify as a faction under our model. It will, therefore, require parties seeking to help vulnerable sections to organise themselves on non-identitarian or multi-

108 Maurice Duverger, Political Parties, translated by Barbara North \& Robert North (New York: John Wiley \& Sons, 1954) at 217f.

109 Reilly, supra note 83. 
identitarian bases if they are to win elections. This should not worry us too much because in a well-functioning dividual ballot system, concerns of disadvantaged groups should be part of the broad church built by the centrist parties; at any rate, centrist parties are likely to be less hostile ideologically to inclusive parties representing disadvantaged groups than they will be to exclusionary factions (and, therefore, more willing to accommodate the policy preferences of nonfactional small parties in exchange for legislative support in the checking and opposition chamber).

The total exclusion of factions from politics may not be desirable, because if they have no stakes in the system, they will seek to upend it. Furthermore, organising a polity solely around a moderated majoritarian system (through a dividual ballot) may reduce the ideological distance between the major parties too much — as all the large parties are nudged towards the median voters, there is a danger that they become mutually indistinguishable, and dramatically reduce voter choice. For both these reasons, the checking and appointing chamber in moderated parliamentarism is elected proportionally through a categorical, cardinal, vote. This allows factions some voice in the system, without letting them close to executive power. It also keeps the larger parties on their toes, for they are constantly forced to appeal to voters of smaller parties without losing the median voter. Essentially, the bicameral system forces parties to stretch across the extant political spectra, rather than artificially nudge them towards the centre, leaving swathes of voters without effective representation. A system in which all representation was proportional would struggle to check or moderate factions. It may even incentivise factionalism, for it may even be easier for a small party to secure $10 \%$ of the vote share through a distinctive polarising campaign than by competing with the larger parties that speak to and for all the people. ${ }^{110}$ Unmixed proportional systems, therefore, can exert a significant centrifugal force on the polity by encouraging smaller parties to distinguish

110 See Daniel Weinstock, "Sites of Deliberation in Contemporary Electoral Systems" (2015) 9:2 Journal of Parliamentary \& Political Law 291 at 301 (on "targeting"). 
themselves by operating as factions. ${ }^{111}$ The only ways to cancel this centrifugal incentive in an unmixed proportional system is to either impose very (rather than 'reasonably') high proportionality thresholds for converting votes to seats, or to ban extremist parties through party-ban mechanisms. Moderated parliamentarism avoids both of these extreme responses. Like first-past-the-post systems, these heavy-handed exclusionary tools can be counterproductive, inasmuch as they can fuel a faction's politics of resentment in an 'unfair' system. ${ }^{112}$ Sure, unmixed proportional systems may yet allow that the legislature - acting as a whole - balances out competing interests. But this cannot be ensured: in particular, if factions hold the balance of power, they may have an enormous influence on governmental policy. Furthermore, the polity can be irreparably damaged by too many factional parties wielding governmental influence or power, even if the legislature as a whole represents all major factions. In moderated parliamentarism, factions have a limited expressive platform in the checking and appointing chamber, and may occasionally wield the power to influence legislative power in exchange for supporting governmental proposals. Even then, to have a meaningful influence, they will still need to count as one of the five (or so) largest parties in the checking and appointing chamber only then can they secure a seat in the joint conference committee which hammers out compromises. Factions in moderated parliamentarism are

111 This may well be the most significant reason for preferring moderated parliamentarism over a Greek-style unicameral legislature that is elected on a proportional basis, but the largest party is allocated a large number of bonus seats (say 50) to secure its majority in the chamber. Such a system can approximate to many other benefits of moderated parliamentarism, but fails to provide a sufficiently centripetal impetus to the larger parties, promoting political polarization: George Tsebelis, "The Greek Constitution from a Political Science Point of View” (2014) 2014:42 Greek Political Science Review 145 at 166.

112 Daly \& Jones, supra note 106; Party bans are a key technology for 'militant democracies'. See also, Jerg Gutmann \& Stefan Voigt, "Militant Constitutionalism: A Promising Concept to Make Constitutional Backsliding Less Likely?" (2021) Public Choice, who distinguish militant democracy from militant constitutionalism. 
provided some space within the system to ensure that they don't have the incentive to destroy the system. But their influence and power within the system is kept firmly in check. There is no ideal approach to factions in politics — their existence itself is unideal. Moderated parliamentarism believes in charting a course that discourages and manages them, rather than outlawing them or letting them flourish.

Mixed bicameralism therefore optimises the strengths and weaknesses of both major types of electoral systems. And, it does so better than a hybrid or mixed electoral system. The latter system seeks to combine the virtues of the two systems in the same assembly — its success in doing so has been doubted. Mixed bicameralism, on the other hand, maximises the virtues and moderates the illeffects of each system in different chambers. Michalak shows that "mixed electoral systems certainly are - apart from the two existing, traditional types of electoral systems - a separate, third class of electoral systems ... they have created a completely new entity which cannot be reduced to the sum of the results produced by their majoritarian and proportional components". ${ }^{113}$ Mixed bicameralism, on the other hand, preserves the two traditional systems in each chamber, albeit moderated. Unlike mixed electoral systems, mixed bicameralism allows only the majoritarian part of the representative unit to select the political executive, while reserving the important checking and appointing functions for the proportional part. Furthermore, a dividual ballot flourishes in a multiparty system - where electoral outcomes are more likely to be uncertain — rather than a two-party one. There is no point ranking or approving multiple candidates in a two-horse race: it makes no difference whether the ballot is categorical or dividual, or cardinal or preferential, if there are only two candidates in the fray. A proportional chamber, which encourages the growth of multiple parties, may be necessary to ensure that a de jure preferential system does not become a de facto first-past-the-post two-party system. These nuanced outcomes would be impossible to achieve in a mixed electoral system that constitutes a unicameral assembly.

113 Michalak, supra note 18 at 103. See also Aroney \& Thomas, supra note 100. 


\section{Conclusion}

In this article, I have first summarised an idealised account of the functions of a political party in a healthy democracy developed in an earlier article. That account emphasised their Janus-faced role as intermediaries between the state and its people, which they perform by lowering key information and transaction costs in a democracy. Parties are therefore simultaneously public and private. Party systems that successfully reduce political participation costs, voters' information costs, policy packaging costs, and ally prediction costs grease the wheels of representative democracy and are indispensable to its smooth operation. In order to aid parties in performing their intermediary function well, constitutions should seek to optimise four key principles in relation to political parties. First, they ought to protect the purposive autonomy of parties, and align their rights and duties closely to their hybrid public-private character. Second, constitutions should optimise the number of parties such that there are enough parties to represent every salient voter-type, but not so many that voters' information costs become unaffordable. Third, constitutions should ensure the separation of the parties from the state so that no party is able to entrench itself in the institutions and offices of the state. Breach of this principle increases the political participation costs of the supporters of opposition parties. Finally, the anti-faction principle requires that constitutions should encourage parties to cater to the interests of all the people, rather than those of merely a sub-section thereof. Factional parties increase the political participation costs of excluded minorities. They also make policy packaging difficult.

Relying upon these claims, the article made a case for moderated parliamentarism. Moderated parliamentarism is a sub-type of semiparliamentarism, i.e. systems in which the political executive must enjoy the continuous confidence of one (and only one) chamber of a bicameral legislature to remain in power. In the moderated version of this regime-type, the two chambers are elected through two different electoral systems: a confidence and opposition chamber elected on a majoritarian basis, and a checking and appointing chamber elected on a proportional basis. Each electoral system is itself moderated: in moderated parliamentarism, the majoritarian ballot is 
dividual (either through approval vote or preferential vote, rather than first-pastthe-post), whereas the proportional system applies a reasonably demanding threshold before translating votes into seats. The article argued that moderated parliamentarism optimises the benefits of different regime types and electoral systems in a way that optimizes the proposed constitutional principles, and context permitting — can be a good theoretical model for representative democracies.

Moderated parliamentarism is a relatively thin constitutional design model inasmuch it is not pre-committed to too many thick normative values, besides democracy. It is compatible with many conceptions of liberalism and at least some conceptions of socialism. ${ }^{114}$ Unlike many other separationist accounts, especially those that draw their inspiration from the US federal system, moderated parliamentarism is not predisposed to a minimalist or libertarian state. In a presidential system, veto players can create impasse, defaulting to state inaction on policy matters. Over time this leads to a neoliberal or libertarian small state. Moderated parliamentarism, on the other hand, does not default to either a minimalist or a maximalist state. By providing effective checks without the possibility of an irresolvable deadlock, it ensures that state action as well as inaction is a deliberated choice of governing institutions, rather than a status quoist default forced by an impasse. Its vision of constitutionalism embraces both its negative and positive dimensions: moderated parliamentarism assumes that effective constitutions restrain, permit, and facilitate the exercise of state power. ${ }^{115}$ Moderated parliamentarism should therefore be additionally attractive for its compatibility with a wide range of ideological commitments in a constitution, as well as with constitutions that choose not to align themselves with any thick ideology other than representative democracy.

One pragmatic objection to moderated parliamentarism may be that the preferential vote system for the confidence and opposition chamber may be

114 I speak, of course, of democratic socialism. On constitutionalism in authoritarian socialist countries, see Bui Ngoc Son, Constitutional Change in the Contemporary Socialist World (Oxford: Oxford University Press, 2020).

115 Waldron, supra note 16; Barber, supra note 16. 
difficult for the people to understand, especially when illiteracy afflicts a significant portion of the electorate. The first response to this feasibility worry is that preferential vote is only one way to design a dividual ballot: an approval vote is also dividual, without necessitating any ranking. Secondly, although preferential voting is indeed harder to explain or administer than first-past-thepost, we must distinguish between the ease of understanding what the voter needs to do from understanding how the votes are counted. Ideally, both aspects should be perfectly transparent to an electorate, and a moderated parliamentary system should undertake educational programmes to explain both aspects. However, the difficulty of explaining preferential vote mainly afflicts the vote counting stage, entailing various elimination rounds. Ranking multiple options is intuitively accessible to humans, and there should be little difficulty in designing voter-friendly ballots where they can rank their preferences. When Estonia transitioned from a categorical voting system to single transferable vote (which is even more complex than ranked-choice voting because it entails multimember, rather than single-member, constituencies), the new system was found to be "not too complex to handle even for voters and officials used to onecandidate fake elections". ${ }^{116}$

Tweaks can be adopted to make the system more feasible: limited preferential vote only requires/allows rankings of a voter's top two or three candidates, rather than the more laborious demand of ranking all candidates in a lengthy ballot; contingent vote eliminates all but the top two candidates after the first round of counting and reallocates their votes to these two remaining candidates; optional vote permits voters to rank their candidates, but does not mandate it, so that a categorical ballot cast for a single candidate is still valid as the voter's first choice. These simple tweaks can still accrue the benefits of a preferential vote while making the system simpler to explain and to administer. In any case, most of the feasibility concerns about preference voting tend to apply to preferential ballots in multi-member constituencies that use a complicated 'group voting'

116 Rein Taagepera, “STV in Transitional Estonia” (1996) 34:1 Representation 29 at 36. 
ticket. ${ }^{117}$ What is proposed in moderated parliamentarism is preferential vote in single-member constituencies (aka alternative vote, ranked-choice vote, instant runoff), which is far more intuitive and far less complicated.

Moderated parliamentarism is a theoretical hypothesis, that will need confirmation through empirical evidence. Like any self-consciously acontextual theoretical model, it is not offered as an all-things-considered prescription. In constitutional design, context matters as much as norms do. Nor is moderated parliamentarism, on its own, sufficient safeguard for the four principles we have identified in this article. These principles demand a lot else from a constitution: a robust protection of opposition rights, stringent campaign finance regulations, ${ }^{118}$ protection of the autonomy (from parties as well as from wealth) of truth-telling institutions such as the media and universities. They require an independent, non-partisan, judiciary and fourth branch offices. And much else beside. Moderated parliamentarism is best seen as a theoretical model that may be used as a yardstick to test existing structures: both empirically and theoretically. ${ }^{119}$

Political parties are the life-blood of representative democracy. If democracy is to survive, political parties need to be supported and improved, not eliminated. Hence the four political principles that I argue should inform constitutional design of democracies. Moderated parliamentarism could be one way of supporting a healthy party system, with mostly healthy parties - a necessary, albeit insufficient, condition for a flourishing and stable constitutional democratic regime.

117 Marian Sawer \& Anika Gauja, "Party Rules: Promises and Pitfalls" in Anika Gauja \& Marian Sawer, eds, Party Rules? (Canberra: ANU Press, 2016) 1 at 1, 17.

118 Tarunabh Khaitan, "Political Insurance for the (Relative) Poor: Constitutionalism Could Resist Plutocracy" (2019) 8:3 Global Constitutionalism 536.

119 One interesting way of making normative and theoretical scholarship to speak to each other is articulated in Archon Fung, "Democratic Theory and Political Science: A Pragmatic Method of Constructive Engagement” (2007) 101:3 American Political Science Review 443. 